\title{
The Taphonomy of Dinosaurs from the Upper Jurassic of Tendaguru (Tanzania) Based on Field Sketches of the German Tendaguru Expedition $(1909-1913)^{1}$
}

\author{
Wolf-Dieter Heinrich ${ }^{2}$
}

With 23 figures and 2 tables

\begin{abstract}
Tendaguru is one of the most important dinosaur localities in Africa. The Tendaguru Beds have produced a diverse Late Jurassic (Kimmeridgian to Tithonian) dinosaur assemblage, including sauropods (Brachiosaurus, Barosaurus, Dicraeosaurus, Janenschia), theropods (e.g., Elaphrosaurus, Ceratosaurus, Allosaurus), and ornithischians (Kentrosaurus, Dryosaurus). Contrary to the well studied skeletal anatomy of the Tendaguru dinosaurs, the available taphonomic information is rather limited, and a generally accepted taphonomic model has not yet been established. Assessment of unpublished excavation sketches by the German Tendaguru expedition (1909-1913) document bone assemblages of sauropod and ornithischian dinosaurs from the Middle Saurian Bed, Upper Saurian Bed, and the Transitional Sands above the Trigonia smeei Bed, and shed some light on the taphonomy of the Tendaguru dinosaurs. Stages of disarticulation range from incomplete skeletons to solitary bones, and strongly argue for carcass decay and post-mortem transport prior to burial. The sauropod bone accumulations are dominated by adult individuals, and juveniles are rare or missing. The occurrence of bones in different superimposed dinosaurbearing horizons indicates that skeletal remains were accumulated over a long time span during the Late Jurassic, and the majority of the bone accumulations are probably attritional. These accumulations are likely to have resulted from long-term bone imput due to normal mortality events caused by starvation, seasonal drought, disease, old age and weakness. The depositional environment of the Middle and Upper Saurian Bed was mainly limnic to brackish in origin, while the palaeoenvironment of the Transitional Sands was marginal marine.
\end{abstract}

Key words: Dinosauria, taphonomy, Late Jurassic, Tendaguru, East Africa.

\section{Zusammenfassung}

Tendaguru zählt zu den bedeutendsten Dinosaurier-Lagerstätten Afrikas. Aus den Tendaguru-Schichten sind zahlreiche Skelettreste von Sauropoden (Brachiosaurus, Barosaurus, Dicraeosaurus, Janenschia), Theropoden (z.B. Elaphrosaurus, Ceratosaurus, Allosaurus) und Ornithischiern (Kentrosaurus, Dryosaurus) geborgen worden. Sie stammen aus der späten Jura-Zeit (Kimmeridge - Tithon). Während der Skelettbau der Tendagurusaurier gut untersucht ist, wirft die Taphonomie des Sauriervorkommens von Tendaguru noch immer Fragen auf. Unklar ist bislang, wie die enormen Anreicherungen von Dinosaurierknochen in den Tendaguru-Schichten zustandekamen. Unveröffentlichte Grabungsskizzen der Deutschen Tendaguru Expedition (1909-1913) erweitern unsere Kenntnisse über die Taphonomie der Tendagurusaurier. In den ausgewerteten Grabungsskizzen sind Knochenansammlungen von Sauropoden und Ornithischiern aus dem Mittleren und Oberen Sauriermergel sowie aus den Übergangsschichten über der Trigonia smeei-Schicht dokumentiert. Die Lage und der Erhaltungszustand der Funde lassen auf erheblichen Zerfall der Kadaver und post-mortalen Transport von Skelettelementen vor der Einbettung schließen. Das Vorkommen von Saurierknochen in mehreren übereinanderliegenden Profilabschnitten der Tendaguru-Schichten zeigt, daß Skelettreste während der späten Jura-Zeit über einen längeren Zeitraum hinweg akkumuliert wurden. Die Ansammlungen von Skelettresten gehen wahrscheinlich auf „normale“ Sterbe-Ereignisse zurück, wie z. B. Verhungern, Verdursten, Kankheit, Altersschwäche und jahreszeitliche Dürre. Als Ablagerungsraum der Mittleren und Oberen Saurierschicht kommt ein küstennaher limnischer, zeitweise wohl auch brackischer Küstenstreifen in Betracht. Die knochenführenden Übergangsschichten unter- und oberhalb der Saurierschichten sind randlich marine Ablagerungen.

Schlüsselwörter Dinosaurier, Taphonomy, Oberjura, Tendaguru, Ostafrika.

\section{Introduction}

Tendaguru in southeastern Tanzania, East Africa, has yielded one of the most important Late Jurassic dinosaur assemblages. The first dinosaurs were discovered by B. Sattler in 1907 (Hennig 1914a, Wild 1991), and E. Fraas was the first to excavate dinosaurs in the vicinity of Tendaguru Hill in September 1907 (Wild 1991). Shortly afterwards, Fraas (1908) described and figured some

\footnotetext{
1 The paper is dedicated to Professor Dr. W. Janensch (1878-1969), leader of the German Tendaguru expedition (1909-1913), in appreciation of his outstanding contributions to the understanding of African dinosaurs.

2 Museum für Naturkunde, Institut für Paläontologie, Invalidenstr. 43, D-10115 Berlin, Germany. Received January 1999, accepted May 1999
} 
of these bones as "Gigantosaurus" africanus (= Barosaurus africanus) and "Gigantosaurus" robustus (= Janenschia robusta). Extensive collections of dinosaurs were made by the German Tendaguru expedition between 1909 and 1913 (Janensch \& Hennig 1909; Hennig 1912a, b; Janensch $1914 \mathrm{a}, \mathrm{c}$ ), followed by field seasons of the British Tendaguru expedition between 1924 and 1931 (e.g., Migeod 1927, 1930, 1931; Parkinson 1930). The German and British expeditions yielded spectacular collections of dinosaurs and since that time Tendaguru has been known as one of the world's most important Upper Jurassic dinosaur localities.

Whereas the British dinosaur collection remained undescribed (Russell et al. 1980), the German dinosaur material from Tendaguru has been well studied. Sauropods (e.g., Brachiosaurus, Dicraeosaurus), theropods (e.g., Elaphrosaurus, Ceratosaurus, Allosaurus), and ornithopods (Kentrosaurus, Dryosaurus) were identified and described in a series of monographs. Most of these works concentrated on the anatomical description of the Tendaguru dinosaurs (e.g., Hennig 1925; Janensch 1914b; 1929a, b; 1935, 1950a, 1955, 1961a, b). By contrast, the available taphonomical accounts are rather limited (e.g., Hennig 1912a, b; Janensch 1914a, c, 1929a, b) and detailed excavation plans have not been published so far.

The depositional environment and the origin of the bone accumulations recovered from the Tendaguru Beds are still under debate. Several taphonomic models have been suggested, among them the interpretation of Janensch (1914a, c), according to which the Tendaguru Saurian Beds are marginal-marine in origin. The attritional and catastrophic bone accumulations and remarkable pre-burial taphonomic biases have been taken into consideration in this model. Janensch $(1914 a, c)$ argued that dinosaurs had been trapped and killed in the mud or 'mireholes' of lagoons that were temporarily exposed by ebbing tides (see also Hennig 1912a, b). This was followed by carcass flotation and decay in shallow water, prior to burial. Bone beds mainly consisting of disarticulated skeletal elements of Dryosaurus or Kentrosaurus were thought to result from sudden, catastrophic, mass-mortality events (e.g., Hennig 1912a, 1925; Janensch 1914a, c). Other workers argue that an estuarine environment existed in what is now the Tendaguru area (e.g., Abel 1927, Kitchin 1929, Parkinson 1930, Colbert 1984), and that dinosaur carcasses were washed in by rivers. They were transported downstream and buried close to the mouth of rivers that flowed into the sea. Reck (1925), however, doubted catastrophic mass mortality and interpreted the depositional environment of the Saurian Beds as saline marshes. To date there is no taphonomic model that convincingly explains the enormous accumulations of dinosaur bones in the Tendaguru Beds.

The archive of the Institute of Palaeontology of the Museum of Natural History of the Humboldt University, Berlin, retains unpublished field sketches made by the German Tendaguru expedition (1909-1913). These field sketches are extremely important because primary field records of the expeditions are very scarce. The unpublished field records reveal details of the preservation characteristics of Tendaguru dinosaurs and enable some reassessment of the taphonomic interpretations suggested by previous workers. The main focus of this paper is to document and assess these unpublished Tendaguru field records.

\section{Setting}

\subsection{Geological and palaeontological background}

The Tendaguru Beds that have yielded the dinosaur assemblages crop out in southeastern Tanzania (Hennig 1914b, 1937; Janensch 1914a, c; Aitken 1956, 1961; Kent et al. 1971; Kapilima 1984; Zils et al. 1995a, b; Fig. 1). The sedimentary sequence was named after Tendaguru Hill (= steep hill; Dr. J. Kabudi, Daressaalam, oral communication), which is located about $60 \mathrm{~km}$ northwest of the seaport of Lindi (Fraas 1908, Janensch 1914a, c). The following paragraph briefly summarises the original description by Janensch (1914c).

The Tendaguru Beds represent shoreline deposits that were laid down near an oscillating strandline during Late Jurassic and Early Cretaceous times (Janensch 1914a, c; Russell et al. 1980). There are three sedimentary cylces in the Tendaguru Beds (Hennig 1914b, Janensch 1914c). The series of sediments begins with sandy marls of the Lower Saurian Bed (Untere erste Saurierzone, Janensch 1914c; Unterer Sauriermergel, Janensch 1961a) which measure more than $20 \mathrm{~m}$ in thickness (Fig. 1). These strata pass gradually into the marine sandstones of the $\mathrm{Ner}$ inea Bed (Untere Sandsteinzone, Nerineenzone, Janensch 1914c; Untere Zwischenschichten, Janensch 1961a) which are overlain by greenish- 
grey and reddish sandy marls of the Middle Saurian Bed (Mittlere zweite Saurierzone, Janensch 1914c; Mittlerer Sauriermergel, Janensch 1961a). Janensch (1914c) reports a thickness of about $25 \mathrm{~m}$ for the Nerinea Bed and some $15 \mathrm{~m}$ for the Middle Saurian Bed. The succeeding fine to coarse grained marine sandstones of the Trigonia smeei Bed (Mittlere Sandsteinzone mit Trigonia smeei, Janensch 1914c; Obere Zwischenschichten, Janensch 1961a), which measure about $20 \mathrm{~m}$ in thickness, separate the Middle Saurian Bed from the Upper Saurian Bed (Oberste dritte Saurierzone, Janensch 1914c; Oberer Sauriermergel, Janensch 1961a). The latter consists of greenish-grey and reddish sandy marls which reach some $40 \mathrm{~m}$ in thickness. The Upper Saurian Bed is overlain by sandy shallow marine sediments of the Trigonia schwarzi Bed (Obere Sandsteinzone mit Trigonia schwarzi, Janensch 1914c), the thickness of which was estimated at approximately $5 \mathrm{~m}$.

Sandy or oolitic sediments at the boundaries between the Saurian Beds and the marine sandstone units (Zwischenschichten, Nerinea Bed, Trigonia smeei Bed) have been described as Transitional Beds (Übergangschichten), since marine invertebrates (e.g, belemnites) are associated with skeletal remains of dinosaurs (Hennig 1914b, Janensch 1914c). Transitional Beds containing marine invertebrates and dinosaurs have also been reported from the Nerinea Bed (Janensch 1961a). Sandy deposits below and above the Trigonia smeei Bed have been distinguished as the Lower and Upper Transitional Sands by Russell et al. (1980).

The age of the Tendaguru Beds has been controversial since the first dinosaurs were discovered in the vicinity of Tendaguru Hill (e.g., Janensch 1914c; Dietrich 1925, 1933; Kitchin 1929; Hennig 1937; Aitken 1956, 1961). The age of the Tendaguru Beds ranges from Late Jurassic to Early Cretaceous (e.g., Hennig 1914b; Janensch 1914c; Schuchert 1918, 1934; Dietrich 1933; Hennig 1937; Aitken 1956, 1961; Kapilima 1984), contrary to previous views that placed the sequence in the Cretaceous (e.g., Fraas 1908, Kitchin 1929), and there is general agreement that the Trigonia schwarzi Bed, above the Upper Saurian Bed, correlates well with the Early Cretaceous (e.g., Janensch 1914c, Lange 1914, Zwierzycki 1914, Dietrich 1933, Aitken 1961).

Hennig (1914b, 1937) believed that the Tendaguru Beds represent a nearly continuous sequence without major breaks. By contrast, Parkinson (1930) suggested a disconformity below the Trigonia schwarzi Bed, a view that is strongly supported by palaeontological (Dietrich 1933, Spath 1927-1933, Aitken 1956, 1961) and geological evidence (Aitken 1956, 1961). The invertebrate fossil record indicates an Upper Valanginian (Oberes Valendis) to Aptian age (Dietrich 1933) or Hauterivian to Aptian age (Spath 1927-1933) for the Trigonia schwarzi Bed (Aitken 1956, 1961). The Jurassic-Cretaceous boundary is placed above the Upper Saurian Bed, which is thus regarded as entirely Late Jurassic in age (e.g., Dietrich 1933, Aitken 1956), and below the Trigonia schwarzi Bed, contrary to the opinon of previous workers who positioned this boundary either at the base (e.g., Hennig 1914b, Janensch 1914c), or within the Upper Saurian Bed (e.g., Hennig 1937). The stratigraphic work in the Tendaguru region is concisely summarized by Aitken (1961).

The present report is especially concerned with the Middle and Upper Saurian Beds and the Transitional Sands above the Trigonia smeei Bed. These units of the Tendaguru Beds are now generally considered to be Kimmeridgian to Tithonian in age (Aitken 1956, 1961; Russell et al. 1980; see also Schrank 1999, Schudack et al. 1999). Moreover, charophytes suggest a Kimmeridgian age for the Middle Saurian Bed (Schudack 1999).

The majority of dinosaur remains were recovered from the Middle and Upper Saurian Bed, occuring mainly as incomplete skeletons and solitary bones (Janensch 1914a, c; 1929a, 1961a). By contrast, the Lower Saurian Bed has only yielded a small number of isolated sauropod bones and theropod teeth (Janensch 1929a, 1961a).

The Middle and the Upper Saurian Bed show clear evidence of redeposition (Janensch 1961a: 179). This is consistent with the lithological characters of the matrix from the Middle Saurian Bed from Site Jg (WJ) which was searched for mammals (Heinrich 1998, 1999). The matrix occasionally contains assemblages of oncoids, mud clasts and lithoclasts consisting of reworked caliche nodules (Dr. M. Aberhan, Prof. Keupp, Dr. Schudack; oral communication). The latter were derived from palaeosoils that had developed in the Tendaguru palaeoenvironment, under a warm and seasonally dry (arid or semiarid) climate. In this connection it is interesting to note that the known invertebrate fossil record from the Middle and Upper Saurian Beds, which includes records of freshwater gastropods (e.g., Dietrich 1914, Hennig 1914c), evidence of As- 
mussia (= Estheria) (Janensch 1933), and limnic to brackish ostracods (Schudak et al. 1999) is consistent with the sedimentological data.

Dinosaur bone assemblages, including concentrations of water worn limb bones of sauropods were also frequently found in the Transitional Sands above and below the Trigonia smeei Bed, and some of them show evidence of reworking (Janensch 1961a). Dinosaur remains have also been reported from the Transitional Sands above the Nerinea Bed (Janensch 1961a). The co-occurrence of dinosaur bones and marine to brackish invertebrates in these beds suggests a shallow marine to brackish depositional environment for the Transitional Sands (Janensch 1914c, 1961a).

The marine depositional environment of the Nerinea Bed, Trigonia smeei Bed, and Trigonia schwarzi Bed is indicated by the presence of marine invertebrates, including ammonites (e.g., Zwierziecky 1914, Dietrich 1933, Zeiss 1975), gastropods (e.g., Dietrich 1914, 1933; Hennig 1914c), lamellibranchs (e.g., Lange 1914, Dietrich 1933, Aitken 1961), and brachiopods (e.g., Lange 1914), but these all require further study. Moreover, with regard to the stratigraphic terminology, Aitken (1961) doubted that Trigonia smeei described from the Tendaguru Beds (e.g., Lange 1914, Dietrich 1933) was identical to Trigonia smeei from the type locality of Shapoor in Cutch (India), contrary to Cox (1952) who accepted their synonymy.

The field scetches of the German Tendaguru expedition cover sites in the Middle Saurian Bed, the Upper Saurian Bed, and the Transitional Sands between the Trigonia smeei Bed and the Upper Saurian Bed that yielded a diverse vertebrate fauna. As far as the land vertebrate assemblage of the Middle Saurian Bed is concerned, the dinosaurs are the most common element and include among others Brachiosaurus brancai, Barosaurus africanus, Dicraeosaurus hansemanni, Kentrurosaurus aethiopicus, Dryosaurus lettow-vorbecki, Elaphrosaurus bambergi, Labrosaurus (?) stechowi, Ceratosaurus (?) roechlingi, and Allosaurus (?) tendagurensis (Janensch 1914b, 1925b, 1929a, 1955, 1961a; Hennig 1925). Pterosaurs (Janensch 1914b, Reck 1931, Unwin \& Heinrich 1999) and lizards (Broschinski 1999) and mammals (Heinrich 1998, 1999) also occur.

The land vertebrate fauna of the Upper Saurian Bed is also dominated by dinosaurs, namely by Brachiosaurus brancai, Barosaurus africanus, Janenschia robusta, Dicraeosaurus sattleri, Kentrurosaurus aethiopicus, Elaphrosaurus bambergi,
Labrosaurus (?) stechowi and Ceratosaurus (?) roechlingi (Janensch 1914b, 1929a, 1961, Hennig 1925). Pterosaurs (Reck 1931) and a mammal (Dietrich 1927, Heinrich 1991, 1999) were also reported.

The Transitional Sands below the Upper Saurian Bed and above the Trigonia smeei Bed yielded among others Brachiosaurus brancai, Barosaurus africanus, Janenschia robusta, Dicraeosaurus sattleri, and Kentrurosaurus aethiopicus (Janensch 1961a). Pterosaurs were also described (Reck 1931, Galton 1980).

\subsection{Sites}

Dinosaurs were first discovered at a few sites in the vicinity of Tendaguru Hill (Fraas 1908), and were subsequently collected from approximately one hundred sites during the field seasons of the German Tendaguru expedition between 1909 and 1913. Most of these sites are located close to Tendaguru Hill (see Janensch 1914a: 45; 1925a: 18 ), except for a small number of localities in the Mchuya and Makangaga area that are not considered here. The former is about $40 \mathrm{~km}$, the latter approximately $80 \mathrm{~km}$ north of the Tendaguru region (Janensch 1914a, Fig. 1).

The German Tendaguru expedition was run by W. Janensch (1909-1911), assisted by E. Hennig (1909-1911), H. von Staff (1911), and H. Reck (1912-1913) who was supported by his wife Mrs. Ina Reck née von Grumbkow. The Tendaguru sites were worked intensively, and at important localities, the collecting period extended through three field seasons from 1909 to 1911, for example at Site S (Fig. 1) which yielded the type specimen of Brachiosaurus brancai (Janensch 1914a, c). In 1911, about 500 Africans were involved in the excavations. Together with their families about 900 people temporarily inhabitated the region of Tendaguru Hill (Jaeger 1971).

The excavations met with outstanding success. African field crews supervised by the leaders of the German Tendaguru expedition and native foremen uncovered the bones, which were mapped, labelled, catalogued, packed, carried to the seaport of Lindi, and shipped to Germany (Janensch 1914a). Each site was indicated with lower case or capital letters, Roman numerals or other symbols (e.g., Nr.) combined with Arabic numerals (Janensch 1914a). Janensch (1914a, 1925a) published maps indicating the topographic and stratigraphic position of the principal sites of the Tendaguru area, most of which 
are from the Upper and Middle Saurian Beds. Only a few sites are known from the Tansitional Sands at the base and top of the Saurian Beds. A detailed account of the diggings at Tendaguru and the recovery of dinosaur bones is given by Janensch (1914a).

\subsection{Excavation records}

Documentation of the German Tendaguru expedition is largely incomplete. Records include a detailed field catalogue, containing lists of the dinosaur bones recovered with hand-written notes by Werner Janensch, Edwin Hennig, and Hans Reck. Sketchbooks of the German Tendaguru expedition with pencil and ink drawings by Werner Janensch, Edwin Hennig and Hans Reck, documenting single bones and skeletons, and watercolours of individual skeletal elements, possibly by Ina Reck, are also available. A few topographic quarry plans are also present in the sketchbook. The collection of records also contains Werner Janensch's photo album containing black and white photographs documenting the field seasons from 1909 to 1911 . Most important are photographs of uncovered sauropod skeletons including Dicraeosaurus hansemanni (Site $\mathrm{m})$ and Brachiosaurus brancai (Sites D, S, no). Three oil paintings completed by Ina Reck at Tendaguru Hill in 1912 were recently rediscovered in the Institute of Palaeontology of the Museum of Natural History of the Humboldt-University, Berlin. These paintings give some idea of the size of the quarries and field work at Tendaguru, possibly of Sites $\mathrm{Jg}(\mathrm{WJ})$ and St. This documentation, detailed above, forms the basis for this study.

Nevertheless, taphonomical analysis of the Tendaguru dinosaurs are greatly hampered by the loss of field records. There is, for instance, only a partial field book of the German Tendaguru expedition and this covers the time span before the expedition's arrival at Tendaguru Hill on April 16, 1909. Missing parts of the field book, quarry maps and excavation plans appear to have been destroyed by fire during World War II, possibly as a result of an air raid on November 12,1943 that completely destroyed a collection room containing dinosaurs from Tendaguru. The type material of Dryosaurus lettowvorbecki has been missing since that time.

As mentioned previously, almost 100 dinosaur-bearing sites were discovered by the German Tendaguru expedition between 1909 and 1913. The available field sketches, however, cov- er not more than 15 sites. Skeletal elements are roughly sketched in the quarry plans, partly in pencil, partly with ink. The bones are mostly labelled with arabic numerals combined occasionally with the symbols of the sites (e.g., C1, C2). Preliminary anatomical identifications of the bones are given in the field sketches and the Tendaguru field catalogue. Hand-written notes by $\mathrm{W}$. Janensch indicate that some of these identifications were later reassessed. With a few exceptions, the length and width of the bones are not indicated in the field sketches.

Scale drawings of bone accumulations made with grids were probably lost during World War II, and arrows indicating compass directions are often lacking. Discrepancies between the specimen count given in the Tendaguru field catalogue and bones documented in the excavation sketches indicate that the quarry plans often represent only "snapshots" of the diggings, and do not completely reflect all details of the fossil vertebrate record encountered during the excavations. Moreover, the field sketches lack detailed data with respect to the contemporary fauna and sedimentology of the dinosaur-bearing beds exposed by the digging activities.

Despite these gaps, there is no doubt that the unpublished field records of the German Tendaguru expedition can contribute to a better understanding of the taphonomy of the Tendaguru dinosaurs. The field sketches record approximately the original position of skeletal elements and their position relative to one another. A broad spectrum of disarticulation stages can be recognized, and reveal interesting details of the taphonomic history of the Tendaguru dinosaurs that have not been documented so far. It is noteworthy that much of the skeletal material documented in the field sketches is housed today in the collections of the Palaeontological Institute of the Museum of Natural History, Humboldt University, Berlin. Therefore, some of the preserved field sketches could be "updated" and, for example, augmented with scales and ontogenetic data obtained from palaeohistological examinations of sauropod limb bones (Sander 1999 , in press).

\section{The field sketches}

The majority of field sketches document dinosaur bone assemblages from the Upper Saurian Bed. Only a few quarry maps cover bone accumulations from the Middle Saurian Bed and the 


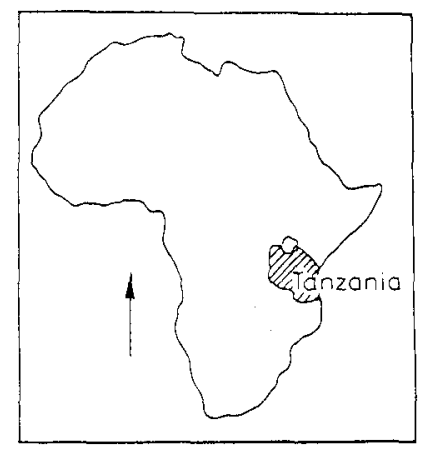

\section{Geographic location and geological structure of Tendaguru, Tanzania}
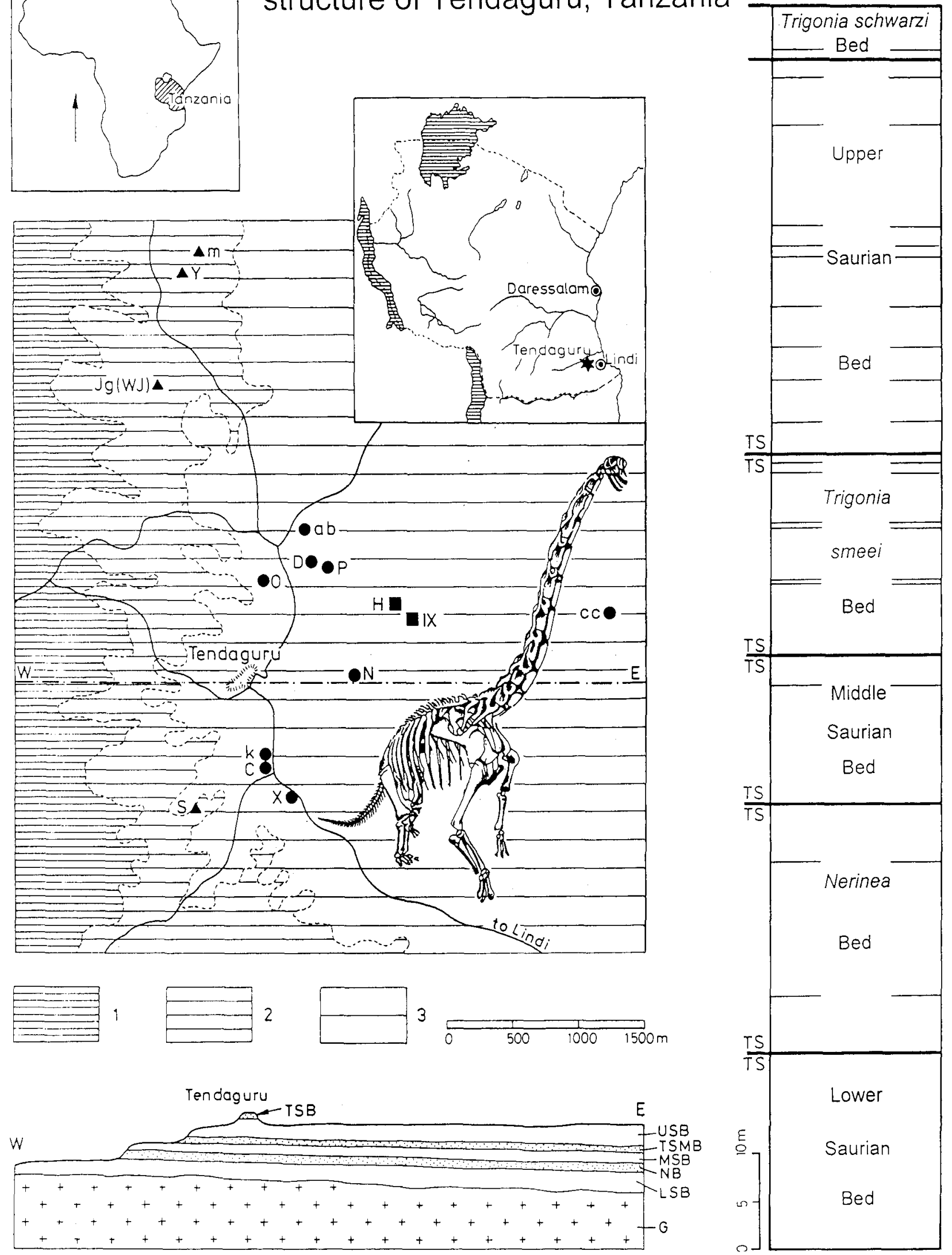

Fig. 1. Map of the Tendaguru area with geological sections and the location of the sites considered in the present account. Data from Hennig (1914b) and Janensch (1914c, 1925a). Note that the marine Nerinea Bed, the two Trigonia Beds, and the Transitional Sands were not mapped in the original site plan (Janensch 1925a: 18) and the Transitional Sands were not distinguished as separate stratigraphical units by Janensch (1914c). 1, Lower Saurian Bed; 2, Middle Saurian Bed; 3, Upper Saurian 
Table 1

Stratigraphic distribution of selected dinosaur-bearing sites in the Tendaguru area.

Stratigraphy Sites

Upper Saurian Bed

Transitional Sands between Trigonia smeei Bed and Upper Saurian Bed

C, D, N, O, P, k, ab, cc, X

Trigonia smeei Bed

Transitional Sands between Trigonia smeei Bed and Middle Saurian Bed

Middle Saurian Bed

Transitional Sands between Middle Saurian Bed and Nerinea Bed

Nerinea Bed

Transitional Sands overlaying the Trigonia smeei Bed. No records are available from the Lower Saurian Bed, the Transitional Sands above and below the Nerinea Bed, and the Transitional Sands below the Trigonia smeei Bed. The topographic and stratigraphic position of the sites detailed in the present taphonomic account is indicated in Figure 1 and Table 1.

As in other vertebrates, the Tendaguru dinosaurs began their taphonomic history as carcasses with complete skeletons, followed by a broad spectrum of disarticulation stages and scattering of individual skeletal elements. Analysis of the field sketches and data given by Janensch (1929a) reveal that four main preservational categories occur in the Tendaguru Beds (Table 2): (1) skeletons, (2) partial skeletons, (3) bone accumulations dominated by disarticulated individual elements, and (4) solitary bones. These main preservational types can be further subdivided by using additional taphonomical criteria such as the degree of disarticulation and loss of bones (see Table 2).
The assignment of bone accumulations to disarticulation stages such as incomplete skeletons or partial skeletons is based on a simplified descriptive scheme that provides unambiguously defined taphonomic categories (Table. 2). According to this classification, partial skeletons only consist of one discrete skeletal unit (e.g., tail or hind limb), in contrast to skeletons that always comprise more than one of those units (e.g., tail and hind limb; fore limb, shoulder girdle and neck).

The skeletal elements are annotated with symbols used by the German Tendaguru field crew. With the exception of Fig. 11, triangles indicate specimens documented either by arabic numerals or by hand-written notes in the Tendaguru field catalogue and descriptions in the literature. The precise position and orientation of these bones is uncertain. The assessment of quantitative data and the azimuth orientation of bones must be treated with caution because of the incompleteness of the excavation records. Reference specimens that were used to calculate the scale for

Table 2

Disarticulation stages of a dinosaur skeleton (simplified). For explanation see text.

\begin{tabular}{lll}
\hline Disarticulation stages & Designation & Skeletal elements \\
\hline A & Complete skeleton & articulated, no loss of bones \\
$\mathrm{B}$ & Complete skeleton & partly articulated, partly disarticulated; no loss of bones \\
$\mathrm{C}$ & Complete skeleton & disarticulated, no loss of bones \\
$\mathrm{D}$ & Incomplete skeleton & articulated, loss of bones \\
$\mathrm{E}$ & Incomplete skeleton & partly articulated, partly disarticulated; loss of bones \\
$\mathrm{F}$ & Incomplete skeleton & disarticulated, loss of bones \\
$\mathrm{G}$ & Complete partial skeleton & articulated, no loss of bones \\
$\mathrm{H}$ & Complete partial skeleton & partly articulated, partly disarticulated; no loss of bones \\
$\mathrm{I}$ & Complete partial skeleton & disarticulated, no loss of bones \\
$\mathrm{K}$ & Incomplete partial skeleton & articulated, loss of bones \\
$\mathrm{L}$ & Incomplete partial skeleton & partly articulated, partly disarticulated; loss of bones \\
$\mathrm{M}$ & Incomplete partial skeleton & disarticulated, loss of bones \\
$\mathrm{N}$ & Bone field & partly associated, partly disassociated \\
$\mathrm{O}$ & Bone field & disassociated \\
$\mathrm{P}$ & Solitary Bone & isolated
\end{tabular}

Continued legende Fig. 1

Bed; TSB, Trigonia schwarzi Bed; USB, Upper Saurian Bed; TSMB, Trigonia smeei Bed; MSB, Middle Saurian Bed; NB, Nerinea Bed; LSB, Lower Saurian Bed; G, gneiss; TS, Transitional Sands.

$\boldsymbol{\Delta}$ - Sites in the Middle Saurian Bed, - - Sites in the Upper Saurian Bed, $\boldsymbol{-}$ - Sites in the Transitional Sands between the Trigonia smeei Bed and the base of the Upper Bed 
several quarry plans are quoted in the captions of the textfigures.

The definition of taphonomic variables used in the description is as follows (Behrensmeyer 1991, Lyman 1996): MNI - minimum number of identified individuals; NISP - number of specimens documented in the field sketches; size of accumulation - area $\left(\mathrm{m}^{2}\right)$ over which skeletal remains are recovered; density - number of specimens documented in the field sketches per $\mathrm{m}^{2}$.

The following anatomical abbreviations are used in the quarry maps: as - astragalus, ca caudal vertebra, c - rib, cc - cervical rib, cd dorsal rib, co - coracoid, cr. - skull, cv - cervical vertebra, do - dorsal vertebra, fe - femur, fi - fibula, he - haemapophysis, hu - humerus, il - ilium, is - ischium, mc - metacarpal, $\mathrm{mt}$ metatarsal, pb - pubis, pm - phalange (manus), pp - phalange (pes), ra - radius, sa - sacrum, sc - scapula, st - sternal plate, tb - tibia, ul ulna, v - vertebra, $\oplus$ - specimen of known ontogenetic age. The right side is indicated by $\mathrm{d}$ and the left by s. Capital or lower case letters with arabic numerals are catalogue numbers of the German Tendaguru expedition.
Further abbreviations: GTE - German Tendaguru expedition, MNHB - Museum für Naturkunde der Humboldt-Universität zu Berlin, IPHB - Institut für Paläontologie am Museum für Naturkunde der Humboldt-Universität zu Berlin.

\subsection{Sites in the Upper Saurian Bed}

\subsubsection{Tendaguru Site $\mathbf{C}$}

Location: Site C is situated approximately $0.7 \mathrm{~km}$ south of Tendaguru Hill.

Stratigraphy: Upper Saurian Bed

Tax on: Barosaurus africanus

Figure: 2

Reference: Janensch (1914a, 1929a, 1961a), GTE field catalogue: 3

Assemblage data

NISP: 37

MNI: 1

Number of taxa: 1

Designation: Single-individual, single-taxon assemblage.

\section{Tendaguru, Site $\mathbf{C}$ Upper Saurian Bed Barosaurus africanus}

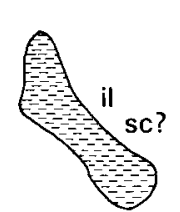

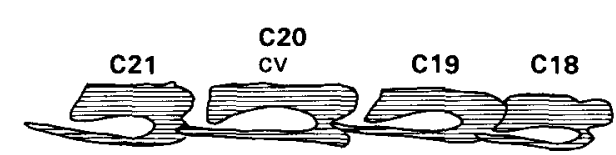

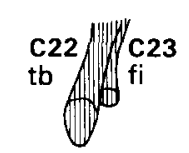

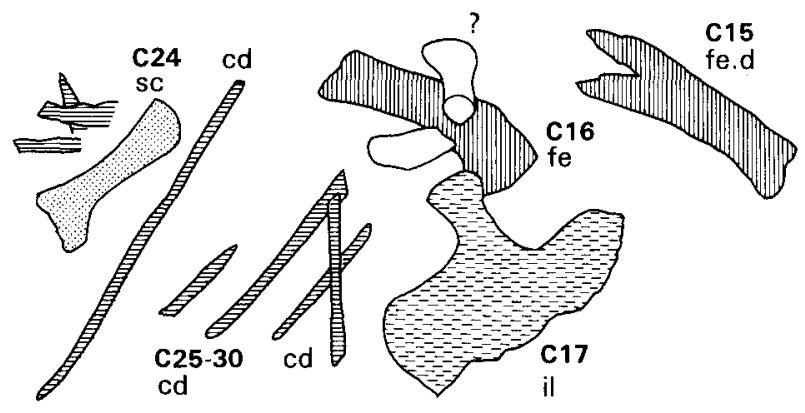

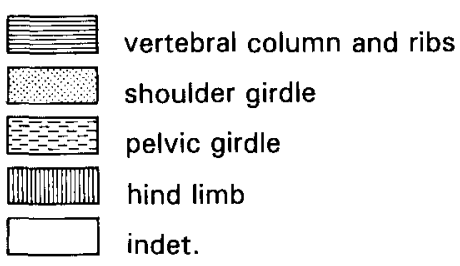

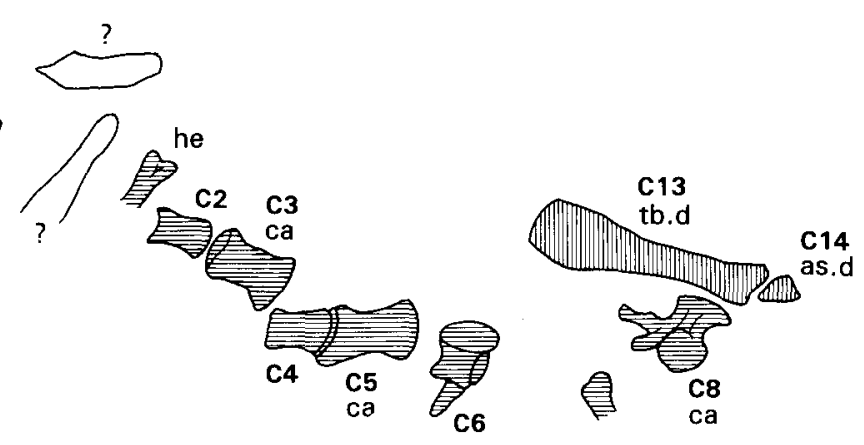

Fig. 2. Incomplete skeleton of Barosaurus africanus from Tendaguru Site C. A few bones are still articulated, but most are disarticulated. The length of the string of cervical vertebrae C18-21 $(2.7 \mathrm{~m})$ was used to calculate the scale for the quarry plan. Redrawn after a field sketch from W. Janensch 
Quarry data

Size of accumulation: approxmately $24.00 \mathrm{~m}^{2}$

Density: approximately 1.54

Modification data

Disarticulation stage: E

Measurements: The length of the caudal vertebrae was measured as $180 \mathrm{~mm}$ (C 2), $200 \mathrm{~mm}$, (C3), and $200 \mathrm{~mm}$ (C5); that of the lemur (C15) at $1320 \mathrm{~mm}$ (Janensch, GTE sketch book). The length of the left tibia (C13) was measured at $890 \mathrm{~mm}$ (Janensch 1961a).

Ontogenetic data: Unknown

Comments: The digging at Tendaguru Site $\mathrm{C}$ commenced in April 1909 (Janensch 1914a: 43). Cervical and caudal vertebrae, an ilium, a femur, tibia, fibula, and an astragalus assigned to an individual of Barosaurus africanus were recovered (Janensch 1929a: 5). Note the dominance of elements of the posterior body region. Most of the skeletal elements were disarticulated, but still closely associated (e.g., tibia and astragalus). The imperfect femur (C15), the tibia (C13), and the astragalus (C14) belong to one single hind limb
(Janensch, GTE field catalogue: 3). The associated tibia (C22) and fibula $(\mathrm{C} 23)$ were found just below a string of articulated cervical vertebrae (C18-21) which measure $2,7 \mathrm{~m}$ in length. A string of articulated caudal vertebrae ( $\mathrm{C} 4$ and 5) is also present. These articulated specimens suggest that some skeletal elements were still connected by soft tissue (ligaments or muscles) prior to burial. Several caudal vertebrae were disarticulated, but apparently still close to their proper anatomical order (Janensch, GTE field catalogue: 3), indicating minimal transport from the position in which the carcass finally came to rest. Extensive damage occured to the ilium and one of the femora prior or subsequent to burial. Most of the long bones and the string of cervical vertebrae show a similar (? west to east) orientation.

\subsubsection{Tendaguru Site D}

Location: Site D is located about $1.0 \mathrm{~km}$ north-north-east of Tendaguru Hill.

Stratigraphy: Upper Saurian Bed

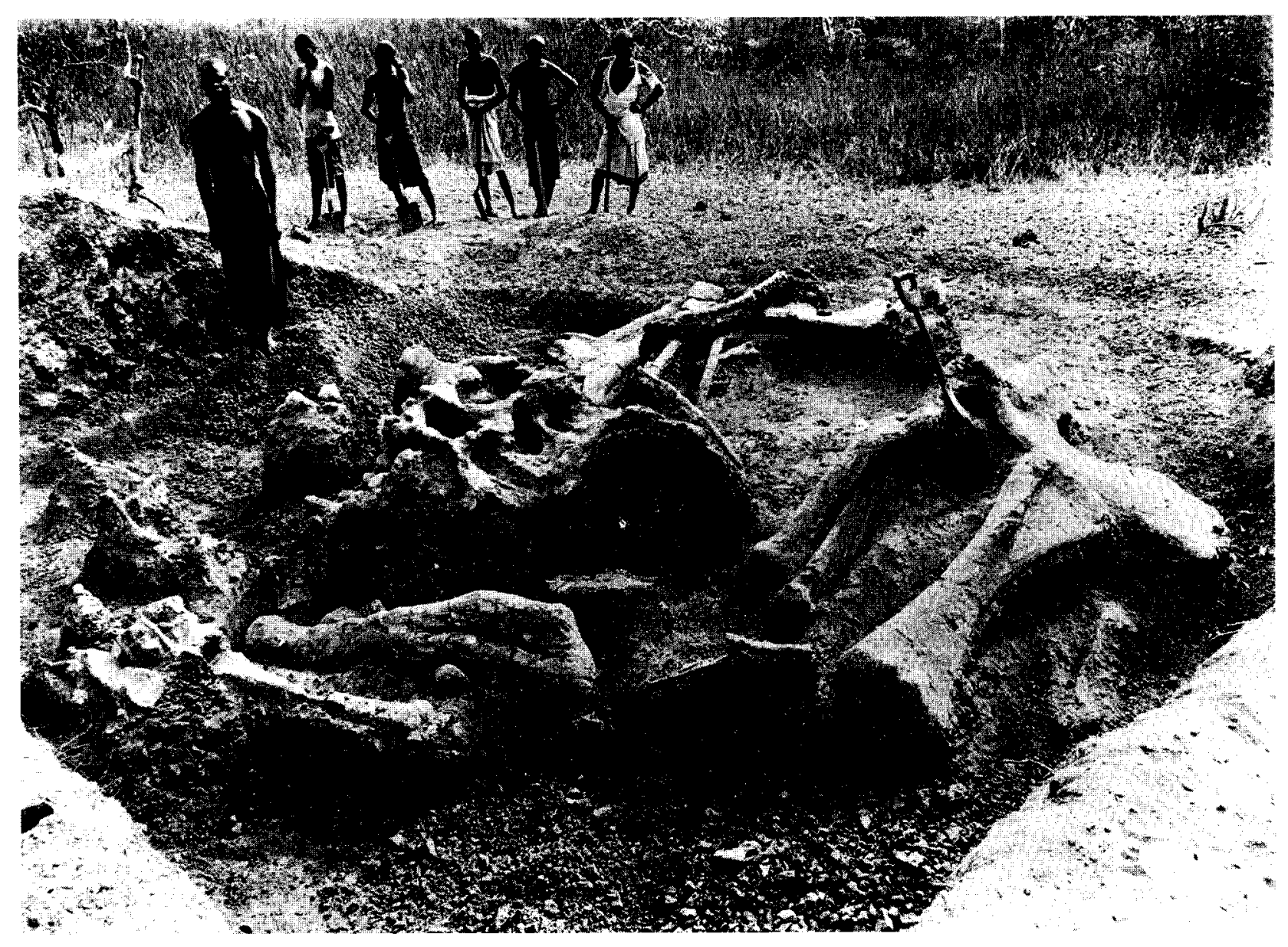

Fig. 3. Incomplete skeleton of Brachiosaurus brancai uncovered from the Upper Saurian Bed at Tendaguru Site D. Photograph: W. Janensch 


\section{Tendaguru, Site D \\ Upper Saurian Bed \\ Brachiosaurus brancai}

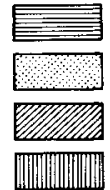

vertebral column and ribs shoulder girdle

fore limb

hind limb

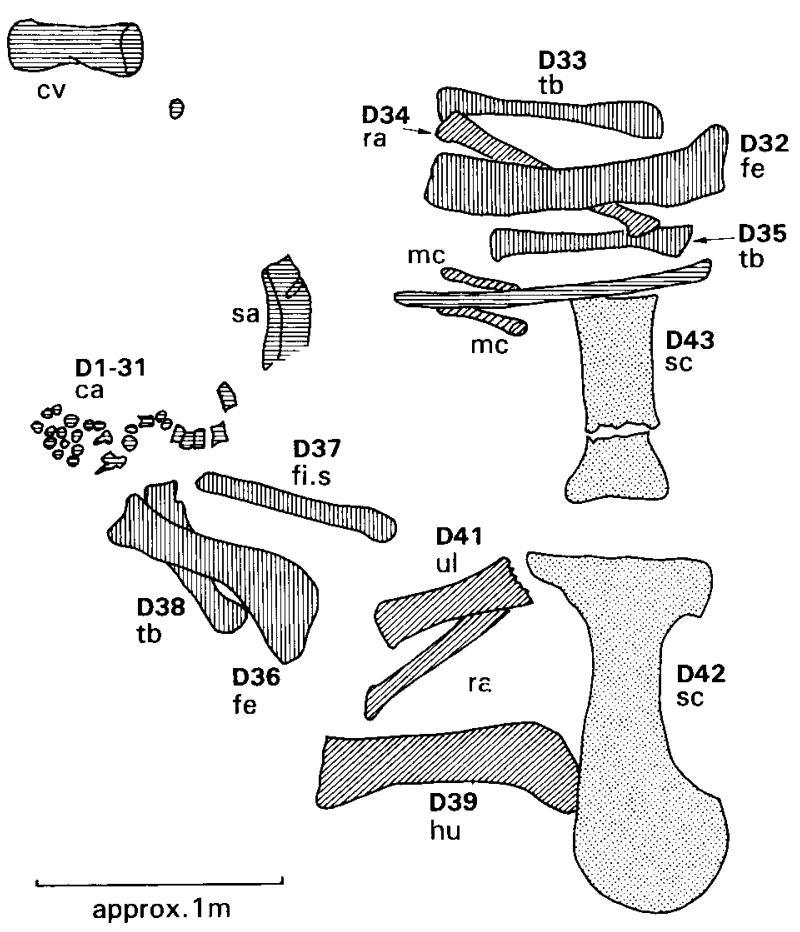

Fig. 4. Incomplete skeleton of Brachiosaurus brancai from Tendaguru Site D. The majority of the skeletal elements are disarticulated, but closely associated. Most caudal vertebrae were found in natural order. Some limb bones rest on top of one another. The measured length of the humerus D $39(1600 \mathrm{~mm})$ was used to calculate the scale for the quarry map. The orientation of the map is not known. Redrawn after a field sketch from W. Janensch

\section{Tax on: Brachiosaurus brancai}

Figures: 3,4

Reference: Janensch (1914a, Fig. 16; 1929a; 1950a), GTE field catalogue: 4-5

Assemblage data

NISP: 50

MNI: 2

Number of taxa: 1

Designation: Multi-individual but single-taxon assemblage

Quarry data

Size of accumulation: approximately $22.00 \mathrm{~m}^{2}$

Density: approximately 2.27

\section{Modification data}

\section{Disarticulation stage: $F$}

Measurements: The length of the limb bones were measured as follows (Janensch 1961a: 230, tab. 18): humerus (D39): $1600 \mathrm{~mm}$, femur (D36): $1550 \mathrm{~cm}$, tibia (D?): $900 \mathrm{~mm}$, and fibula (D?): $940 \mathrm{~mm}$.

\section{Ontogenetic data: Unknown}

Comments: The excavations at Site D commenced on June 21, 1909 (Janensch, GTE field catalogue: 4). The dig yielded a skeleton consisting of a series of 29 caudal vertebrae, a poorly preserved sacrum, pelvic bones (ilium, pubis), dorsal ribs, two anterior limbs without feet, two scapulae, femora, tibiae, and fibulae (Janensch 1914a, 1929a: 7; 1950a; GTE field catalogue: 4-5). Only some of these are documented in the field sketch. The dimensions of the limb bones indicate a medium-sized individual of Brachiosaurus brancai (Janensch 1961a: 230, tab. 18). The series of caudal vertebrae resting next to the badly preserved sacrum was found almost in natural articulation (Janensch 1950a). The association of the remaining disarticulated elements is evident. The scapula (D42) was apparently found lying upon the head of humerus D39, and several other limb bones were found one on top of the other (e.g., tibia D38 and femur D36; radius D34 and femur D32). Plate-like elements such as the shoulder blades seem to be oriented in a nearly horizontal plane, and the scapula D43 and ulna D41 are broken. Most of the elongated limb bones are oriented nearly parallel, and the two scapulae are positioned transverse to the prevailing compass direction of the heavy limb bones.

Most bones documented appear to derive from a single individual preserved as an incom- 
plete skeleton. Originally, the leg bones D34 and D35 were tentatively identified as fibula (?) and radius (?) respectively (Janensch, GTE sketch book). Later, Janensch (GTE field catalogue: 4, hand-written note) identified these bones as fibula and tibia. If properly identified, the existence of three tibiae indicates the presence of at least two individuals of Brachiosaurus brancai. Unfortunately, a reassessment of the limb bones from Site D is not possible, since the location of the collection is not known.

\subsubsection{Tendaguru Site $\mathbf{N}$}

Location: Site $\mathrm{N}$ is located about $0.9 \mathrm{~km}$ east of Tendaguru Hill.

\section{Stratigraphy: Upper Saurian Bed}

Tax on: Brachiosaurus brancai

\section{Figure: 5}

Reference: Janensch (1914a: 44), GTE field catalogue: 19

Assemblage data

NISP: 21

MNI: 1

Number of taxa: 1

Designation: Single-individual, single-taxon assemblage

\section{Tendaguru, Site $\mathbf{N}$}

Upper Saurian Bed

\section{Brachiosaurus brancai}

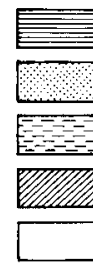

vertebral column and ribs

shoulder girdle

pelvic girdle

fore limb

indet.
Quarry data

Size of accumulation: Unknown

Density: Unknown

Modification data

Disarticulation stage: $F$

Measurements: No measurements are available.

Ontogenetic data: Unknown

Comments: The excavation at Site $\mathrm{N}$ commenced in September 1909 (Janensch, GTE field catalogue: 9). The dig produced a disarticulated incomplete skeleton, with a scapula, complete and fragmentary humerus, radius, and ribs. At a little distance to these bones there were two ischia, a dorsal vertebra, a caudal vertebra, ribs, and a large fragmentary bone (N9) tentatively identified as a fragmentary scapula (Janensch, GTE field catalogue: 19). The bone accumulation at Site $\mathrm{N}$ is dominated by elements of the anterior appendicular skeleton. In total, 21 skeletal elements assigned to Brachiosaurus brancai were collected from site N (Janensch, GTE field catalogue: 19). The bones are attributable to one individual of Brachiosaurus brancai. Except for a few skeletal elements, most of the long bones are oriented nearly parallel, possibly reflecting wave action or current action. Some of them such as the humerus and ischia are broken.

Fig. 5. Incomplete skeleton of Brachiosaurus brancai from Tendaguru Site N. All skeletal elements are completely disarticulated. Scale and orientation of the map are not known. Redrawn after a field sketch from W. Janensch 


\subsubsection{Tendaguru Site 0}

Location: Site $\mathrm{O}$ is located about $0.8 \mathrm{~km}$ north of Tendaguru Hill.

Stratigraphy: Upper Saurian Bed

Taxon: Dicraeosaurus sattleri

Figure: 6 (colour figure on p. 36)

Reference: Janensch (1914a, 1929a, 1961a),

GTE field catalogue: 20

Assemblage data

NISP: 17

MNI: 1

Number of taxa: 1

Designation: Single-individual, single-taxon assemblage

Quarry data

Size of accumulation: approximately $7.00 \mathrm{~m}^{2}$

Density: approximately 2.43

Modification data

Disarticulation stage: F
Measurements: The length of the right limb bones were measured as follows (Janensch 1961 a): humerus (O3): $610 \mathrm{~mm}$, ulna: $410 \mathrm{~mm}$, femur $(\mathrm{O} 2): 980 \mathrm{~mm}$, tibia $(\mathrm{O} 4): 580 \mathrm{~mm}$, fibula $(\mathrm{O} 5)$ : $620 \mathrm{~mm}$.

Ontogenetic data: Janensch (1929a: 10) believed that the skeletal elements originated from a subadult individual of Dicraeosaurus sattleri, however, histological examinations of a right femur $(\mathrm{O} 2)$ and a right humerus $(\mathrm{O} 3)$ suggest that both limb bones belong to an adult individual of this species (Sander 1999, in press).

Comments: Digging by the German Tendaguru expedition's crew at Site O commenced at the beginning of October 1909 (Janensch, GTE field catalogue: 47). Janensch (1914a: 44; 1929a: 10) reported a scapula, pelvic bones, centra of caudal vertebrae, and an imprecisely determined number of fore and hind limb elements, all assigned to Dicraeosaurus sattleri. All bones are disarticulated, but closely associated. There are two groups of long bones oriented with their long axes in two perpendicular directions. The bone accumulation at Site $\mathrm{O}$ is dominated by

Tendaguru, Site 0

Upper Saurian Bed

Dicraeosaurus sattleri
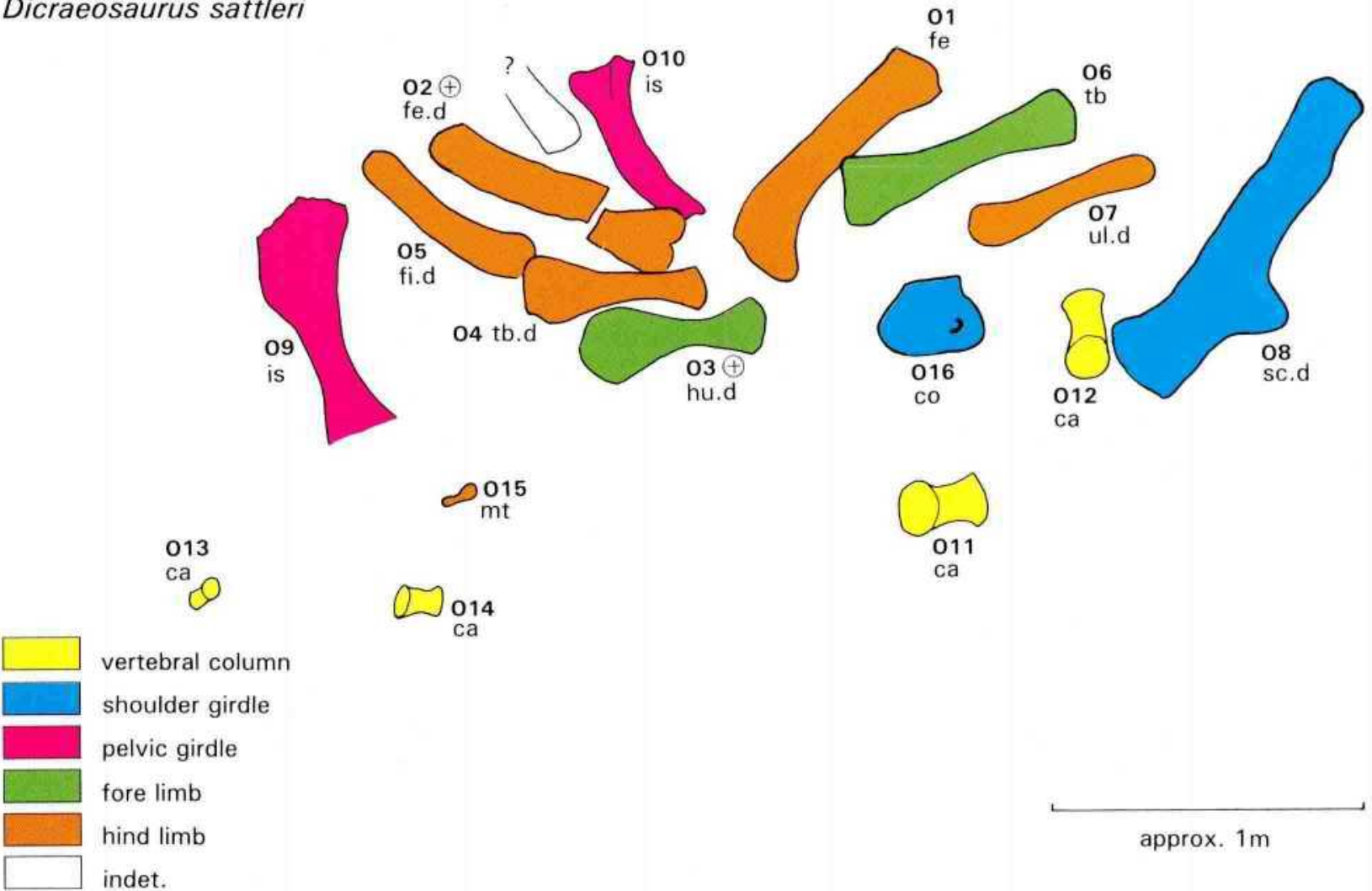

Fig. 6. Incomplete skeleton of Dicraeosaurus sattleri from Tendaguru Site O. The specimen is completely disarticulated. Note the dominance of large limb bones. The measured length of the humerus $\mathrm{O} 3(610 \mathrm{~mm})$ was used to calculate the scale for the quarry map. The orientation of the map is not known. Redrawn after a field sketch from W. Janensch 
heavy limb bones (humerus, ulna, femora, tibiae, fibula). This may indicate that most smaller bones had been almost completely removed from the carcass by currents prior to burial.

\subsubsection{Tendaguru Site $\mathbf{P}$}

Location: Site $\mathrm{P}$ is located at Nterego, approximately $1.2 \mathrm{~km}$ north-north-east of Tendaguru Hill.

Stratigraphy: Upper Saurian Bed

Tax on: Janenschia robusta

Figure: 7 (colour figure on p. 37)

Reference: Janensch (1914a, 1922, 1929a, 1961a), Bonaparte et al. (in press), GTE field catalogue: $21-22$

Assemblage data

NISP: 65

MNI: 2
Number of taxa: 1

Designation: Multi-individual but single-taxon assemblage

Quarry data

Size of accumulation: appoximately $24.00 \mathrm{~m}^{2}$

Density: approximately 2.74

Modification data

Disarticulation stage: $\mathrm{H}$ (find $\mathrm{I}$ ), $\mathrm{K}$ (find III, IV) and L (find II)

Measurements: The length of the left limb bones were measured as follows: humerus (P8): $890 \mathrm{~mm}$, radius (P11): $620 \mathrm{~mm}$, ulna (P12): $670 \mathrm{~mm}$, tibia (P5): $850 \mathrm{~m}$, astragalus (P6): $210 \mathrm{~mm}$.

Ontogenetic data: Unknown

Comments: Digging at Site P commenced in October 1909 (Janensch, GTE field catalogue:

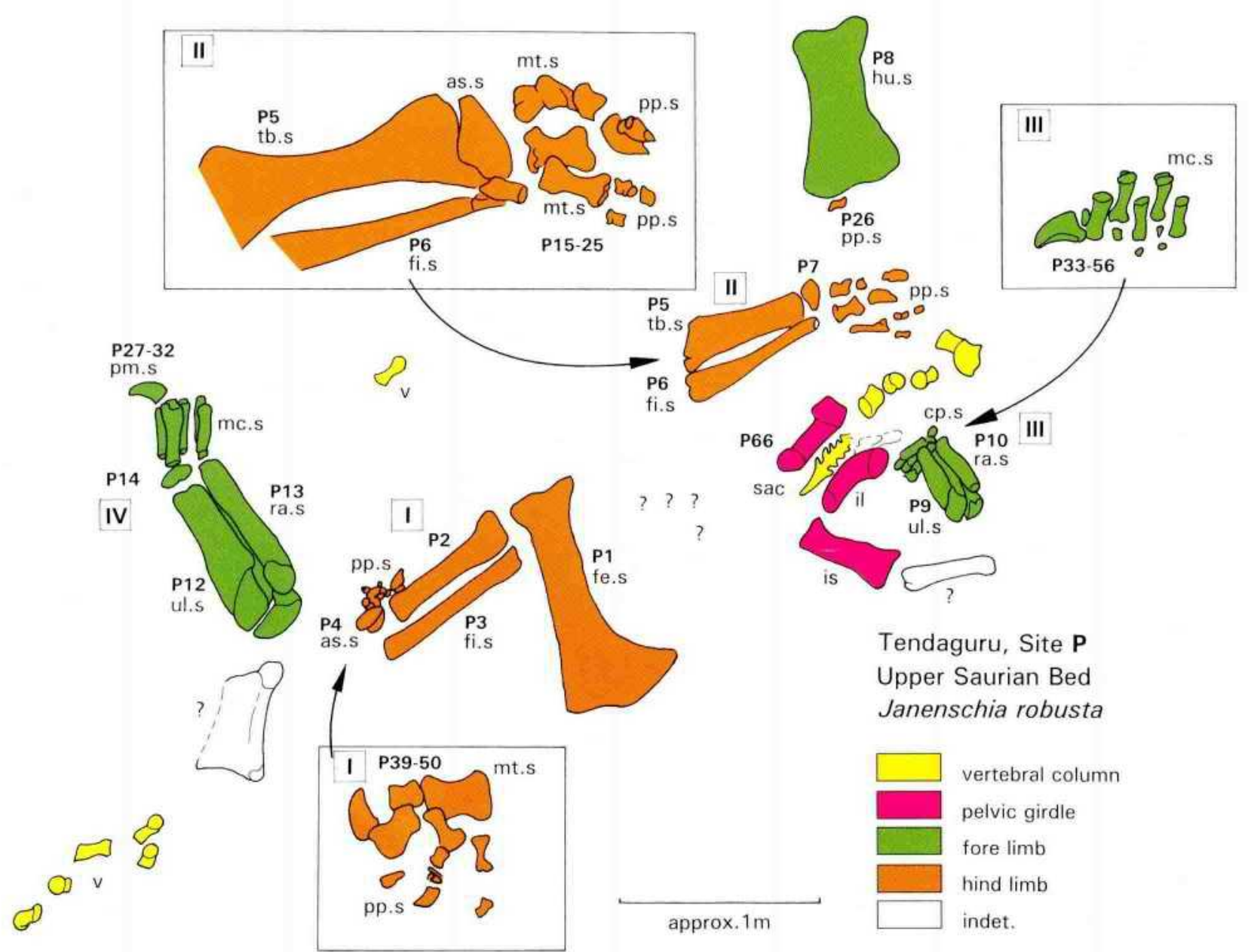

Fig. 7. Partial skeletons of Janenschia robusta from Tendaguru Site P. The bone assemblage consists mainly of two articulated left fore limbs and two articulated left hind limbs. Pelvic elements rest next to the sacrum, and some vertebrae are scattered over the quarry floor. The measured length of the humerus P8 $(890 \mathrm{~mm})$ was used to calculate the scale for the quarry map. The orientation of the map is not known. Redrawn after a field sketch from W. Janensch 
21-22) Four partial skeletons of Janenschia robusta were uncovered, along with additional scattered postcranial bones (GTE field catalogue; Janensch 1922, 1929a; Bonaparte et al., in press). According to Janensch's unpublished excavation sketches and hand-written notes (GTE field catalogue: 21), partial skeleton I consists of a reasonably complete left hind limb, with femur, tibia, fibula, and the foot, including astragalus, metacarpals, and phalanges. The foot bones were still close to their natural anatomical position, while femur, tibia and fibula were slightly disarticulated. Close to this bone accumulation lay partial skeleton IV, represented by an incomplete left fore limb, with radius, ulna, carpal, metacarpals, and phalanges. Nearly all these bones were found in their proper anatomical order. Partial skeleton II consists of an incomplete hind limb, including tibia, fibula, and slightly disarticulated and scattered foot bones (astragalus, metatarsals, phalanges). Partial skeleton III includes the radius, ulna, and the manus of an incomplete left fore limb. In addition to the four partial skeletons, dinosaur bones found at site $\mathrm{P}$ include, among others, a left humerus, a sacrum, and several disarticulated vertebrae scattered over the quarry floor. Janensch (unpublished sketchbook) also noted ribs in his excavation map but no location data are given. The association of these bones with the four partial skeletons remains far from clear. The long axes of the two anterior lower legs (partial skeletons III, IV), the femur of partial skeleton I, and the single humerus were similarly oriented. The two posterior lower legs (finds I, II) are deposited with their long axes perpendicular to the preferred orientation of partial skeletons III and IV.

The low degree of disarticulation, especially of the feet, suggests that soft tissue must have remained attached to the limb bones when they were deposited. The taphonomic evidence also suggests that the partial skeletons were buried close to the point where the original corpses came to rest. In addition, several limb bones show signs of strong weathering due to processes subsequent to burial (Janensch 1914a: 44; 1961a).

Taphonomic and anatomical analyses show that the four partial skeletons belong to a single species, and represent two individuals of $J a$ nenschia robusta (Janensch 1922, 1929a: 7; GTE field catalogue: $21-22$ ). Tendaguru Site $P$ is the only known site, so far, that has provided specific information on the fore and hind limbs of Janenschia robusta.

\subsubsection{Tendaguru Site $k$}

Location: Site $\mathrm{k}$ is situated about $0.7 \mathrm{~km}$ south of Tendaguru Hill.

Stratigraphy: Upper Saurian Bed

Tax on: Barosaurus africanus

Figure: 8 (colour figure on p. 39)

Reference: Janensch (1914a, 1929a, 1961a), GTE field catalogue

Assemblage data

NISP: 50

MNI: 1

Number of taxa: 1

Designation: Single-individual, single-taxon assemblage

Quarry data

Size of accumulation: approximately $19.00 \mathrm{~m}^{2}$

Density: approximately 2.62

\section{Modification data}

Disarticulation stage: E

Measurements: The length of skeletal elements is as follows (Janensch 1961a): left scapula (k34): $1340 \mathrm{~mm}$, right humerus (k37): $970 \mathrm{~mm}$, left ulna (k38): $740 \mathrm{~mm}$, left ischium $(\mathrm{k} 44)$ : $880 \mathrm{~mm}$, left tibia (k41): $860 \mathrm{~mm}$.

\section{Ontogenetic data: Unknown}

Comments: Skeleton k was found close to the remains of Barosaurus africanus from Sites A and B (Janensch 1914a, 1929a). The collecting site was discovered in 1910 (Janensch 1914a). In specimen $\mathrm{k}$, all the main body regions (e.g., skull, axial skeleton, appendicular skeleton) are represented. Janensch (1929a: 6) reported a braincase, maxilla, cervical and dorsal vertebrae, anterior caudal vertebrae, ribs, scapula, coracoid, humerus, ulna, ischium, femur, tibia, and fibula, all assigned to Barosaurus africanus. There are two clusters of skeletal elements, one of which comprises mostly bones of the anterior body region (e.g., braincase, cervical vertebrae, scapula, coracoid, humerus), whereas the other contains bones from the posterior body region (e.g., ischium, femur, tibia, fibula, caudal vertebrae). Only a few skeletal elements are articulated: two strings of dorsal vertebrae (k12 and k13, k14 and $\mathrm{k} 15)$ and two articulated caudal vertebrae (k 20, $\mathrm{k} 21$ ) have been found (Janensch GTE field catalogue: 48). The remaining skeletal elements were disarticulated but still closely associated. Most of the cervical vertebrae and caudal vertebrae were 
apparently found in their natural anatomical order (Janensch, GTE field catalogue: 48), and haemapophyses were associated with the centra of the caudal vertebrae.

The excavation plan (Fig. 8) shows that the limb bones, ischia, scapula, and most of dorsal ribs are embedded with their long axes trending approximately northwest to southeast. The heads of all the dorsal ribs are directed southwards. The fibula is water-worn (Janensch, GTE field catalogue: 49).

The arrangement of the skeletal elements appears to have been modified by water currents. However, the presence of articulated and disarticulated vertebrae found in almost natural anatomical order, the orientation of the dorsal ribs, and the presence of a braincase indicate that the carcass was embedded and decayed close to the place where it came to rest.

\subsubsection{Tendaguru Site ab}

Location: Site ab is located approximately $1.2 \mathrm{~km}$ northnortheast of Tendaguru Hill.

Stratigraphy: Upper Saurian Bed

Taxa: Barosaurus africanus, Dicraeosaurus sattleri, Brachiosaurus brancai ?, Sauropoda indet.

Figure: 9 (colour figure on p. 40)

Reference: Janensch (1961a), GTE field catalogue: $40-41$

Assemblage data

NISP: 37

MNI: 5

Number of taxa: (4)

Designation: Multi-individual, multi-taxon assemblage

Quarry data
Tendaguru, Site k Upper Saurian Bed Barosaurus africanus skull

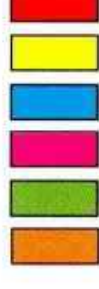

vertebral column and ribs shoulder girdle pelvic girdle

fore limb hind limb

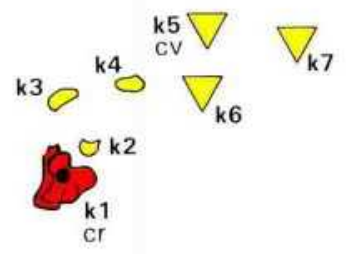

approx. $1 \mathrm{~m}$
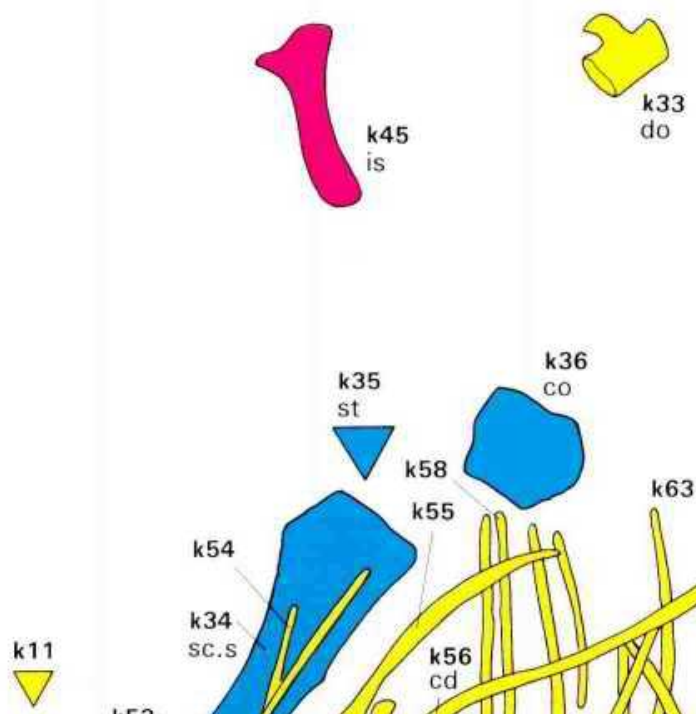

k54

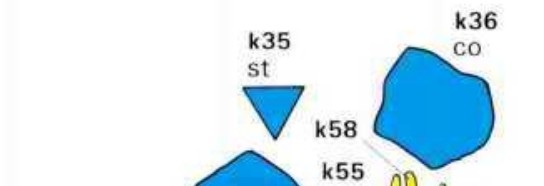

k36

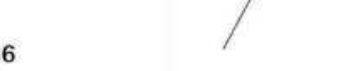

$k 63$
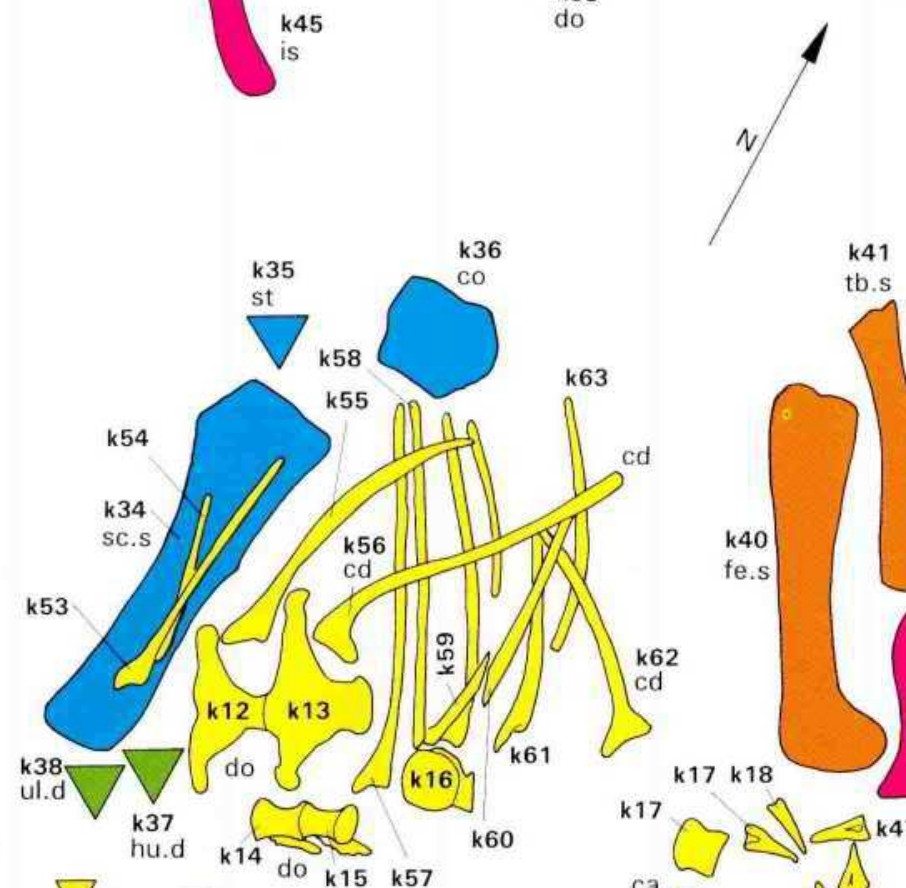

k60

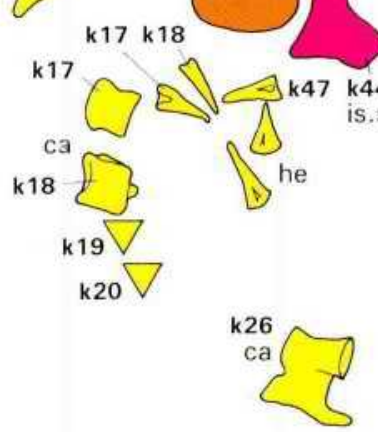

Fig. 8. Incomplete skeleton of Barosaurus africanus from Tendaguru Site k, in an advanced stage of disarticulation, with braincase and cervical vertebrae resting next to the anterior appendicular and trunk elements. The caudal vertebrae are close to the pelvic and hind limb elements. Most skeletal elements are disarticulated, but still closely associated. The measured length of the scapula $\mathrm{k} 34(1340 \mathrm{~mm})$ was used to calculate the scale for the quarry map. Redrawn after a field sketch from W. Janensch 
Size of accumulation: approximately $10.00 \mathrm{~m}^{2}$

Density: approximately 3.61

Modification data

Disarticulation stage: O

Me asurements: Dicraeosaurus sattleri, length of three left humeri: $620 \mathrm{~mm}$ (ab1), $620 \mathrm{~mm}$ (ab2), $580 \mathrm{~mm}$ (ab10); Barosaurus africanus, length of a left tibia (ab4): $650 \mathrm{~mm}$.

Ontogenetic data: Histological data obtained from two left humeri (ab2, ab10) indicate that these limb bones are from two adult individuals of Dicraeosaurus sattleri (Sander 1999, in press).

Comments: There are no excavation data given by Janensch (1914a, 1929a, 1961a), except for the GTE field catalogue. The dig commenced at the beginning of October, 1909. Remains of at least five individual sauropods were recovered from the Upper Saurian Bed at Site ab. All bones are disarticulated and scattered, appar- ently randomly, across the excavation floor. Several bones are imperfect and show distinct signs of breakage. Scattering and mixing of skeletal elements from different taxa and individuals suggests that there was much transport of bones prior to burial. Some of the heavy limb bones are oriented northwest to southeast, others are embedded with long axes trending approximately west to east. The presence of three left humeri (ab1, ab2, ab10) reveals that the diplodocid Dicraeosaurus sattleri is represented by at least three individuals. Two tibiae (ab4, ab5) belong, apparently, to one individual of Barosaurus africanus (Janensch, GTE field catalogue: 40), and two large femora are tentatively assigned to Brachiosaurus brancai (Janensch, GTE field catalogue: 40). A huge uncatalogued limb bone that was not collected (Janensch, field sketch, handwritten note) was tentatively identified as a humerus of Brachiosaurus brancai.
Tendaguru, Site ab Upper Saurian Bed
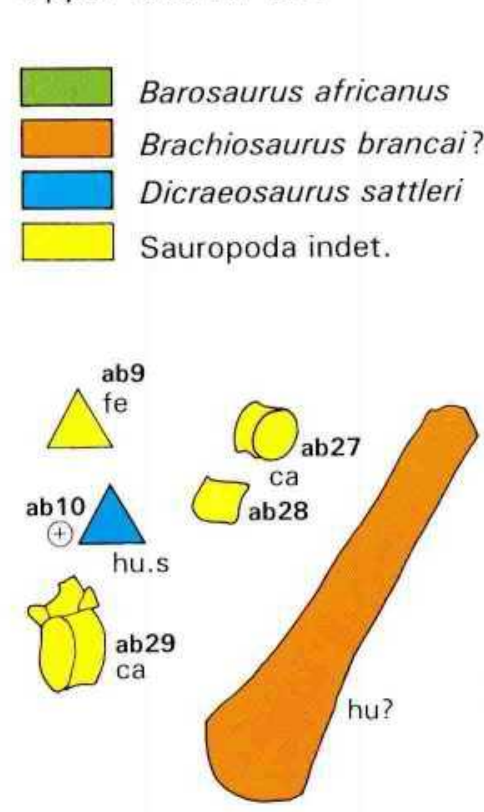
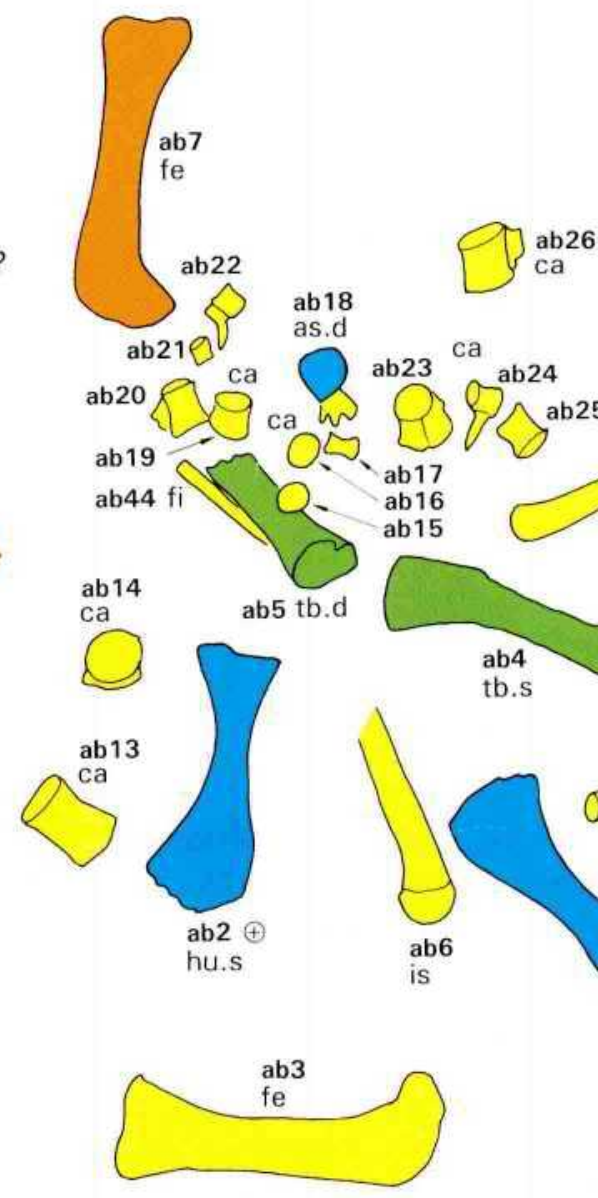
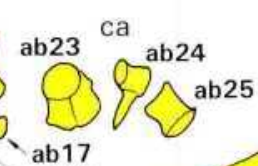
$a b 17$
ab 16 ab 15

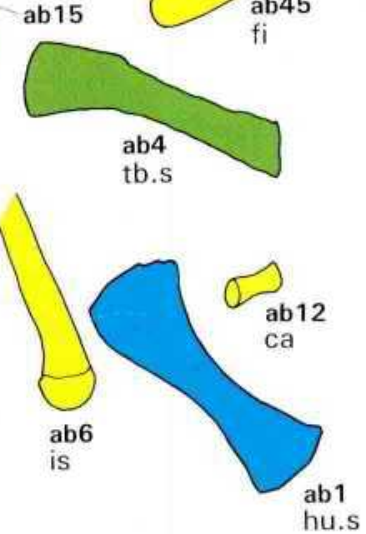

hu.s
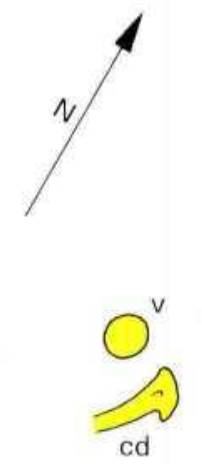

¿a

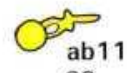

ab46

ab8

$\mathrm{ab}$

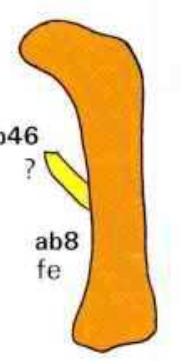

approx. $1 \mathrm{~m}$

Fig. 9. Bone field from Tendaguru Site ab. The accumulation consists mainly of disarticulated sauropod limb bones and vertebrae. Scattering is evident. Note the presence of three left humeri of Dicraeosaurus sattleri, one of which, humerus ab1 $(620 \mathrm{~mm})$, was used to calculate the scale for the quarry map. Redrawn after a field sketch from W. Janensch 


\subsubsection{Tendaguru Site ce}

Location: Site cc is situated approximately $2.9 \mathrm{~km}$ eastnortheast from Tendaguru Hill.

Stratigraphy: Upper Saurian Bed

Taxon: Brachiosaurus brancai

Figure: 10 (colour figure on p. 41)

Reference: GTE-field catalogue: 142

Assemblage data

NISP: 15

MNI: 1

Number of taxa: 1

Designation: Single-individual, single-taxon assemblage

Quarry data

Size of accumulation: approximately $24.00 \mathrm{~m}^{2}$

Density: approximately 1.6

Modification data

Measurements: Length of a right humerus (cc2): $1080 \mathrm{~mm}$.

Disarticulation stage: F

Ontogenetic data: According to Sander (1999, in press), humerus cc2 belongs to an adult individual of Brachiosaurus brancai.
Comments: Taphonomic data for Site cc are poor. Remains found here include cervical vertebrae, a dorsal vertebra, several dorsal ribs, a scapula, a humerus, and bone fragments (Janensch, GTE field catalogue: 142). All elements are disarticulated, but still associated. A preferred orientation of the bones is not discernable.

The documented skeletal elements are mainly from the anterior body region (neck, anterior appendicular skeleton) of a carcass that underwent maceration and decay prior to burial.

\subsubsection{Tendaguru Site $\mathbf{X}$}

Location: Site $\mathrm{X}$ is located about $1.0 \mathrm{~km}$ south-south-east from Tendaguru Hill.

Stratigraphy: Upper Saurian Bed

Taxon: Kentrosaurus aethiopicus, Sauropoda indet.

Figure: 11

Reference: Hennig (1925), GTE field catalogue: $113-114$

Assemblage data

NISP: 115

MNI: (7)

Number of taxa: (2)

Tendaguru, Site cc Upper Saurian Bed Brachiosaurus brancai
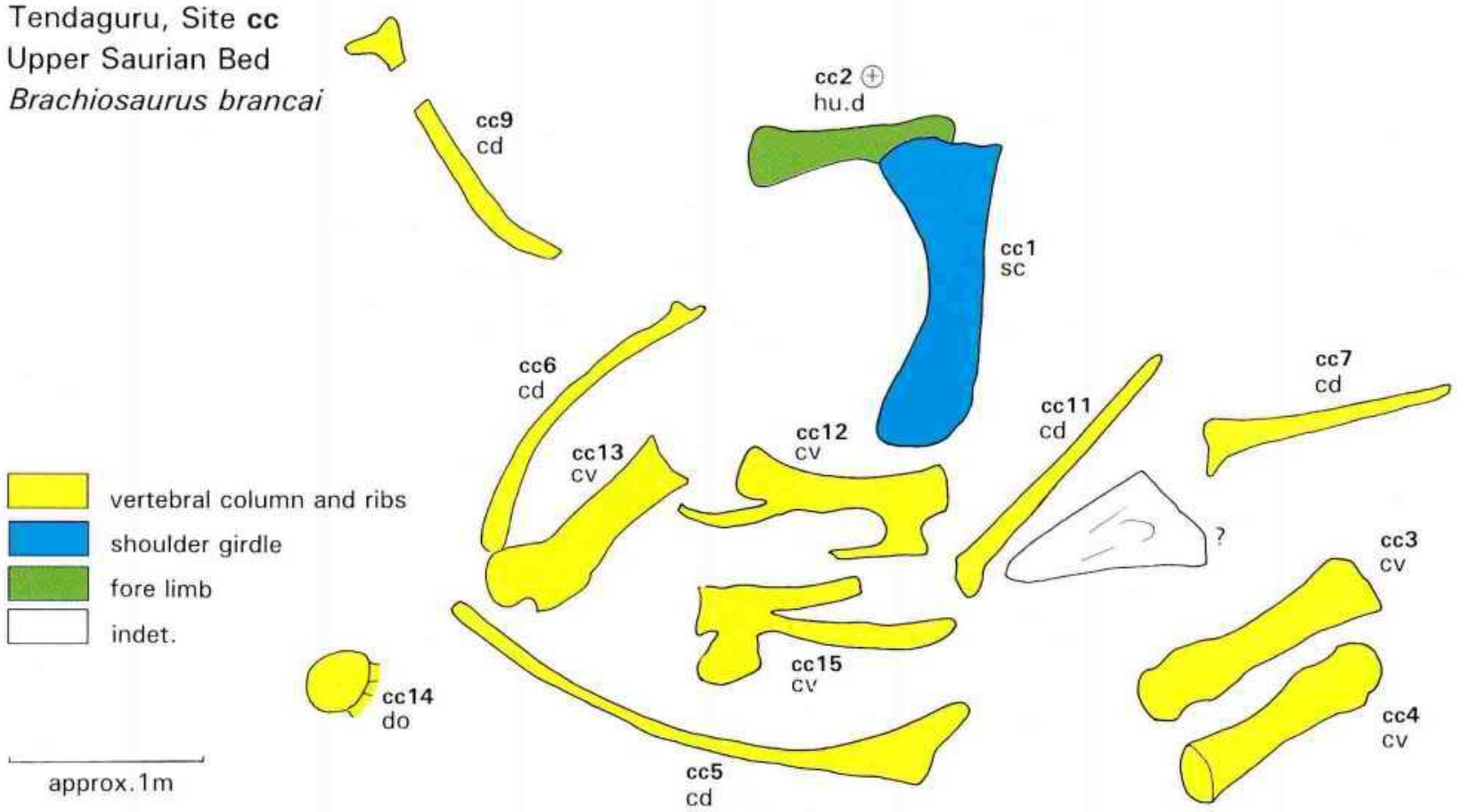

Fig. 10. Incomplete skeleton of Brachiosaurus brancai from Site cc in an advanced state of disarticulation. All bones are disarticulated. The measured length of the humerus $\mathrm{cc} 2(1080 \mathrm{~mm})$ was used to calculate the scale for the quarry map. The orientation of the map is not known. Redrawn after a field sketch from W. Janensch 
Designation: Multi-individual, multi-taxon assemblage

\section{Quarry data}

Size of accumulation: approximately $30.00 \mathrm{~m}^{2}$

Density: approximately 3.83

Modification data

Measurements: See Hennig (1925)

Disarticulation stage: N (O?)

Ontogenetic data: Unknown

Comments: Digging at Site X commenced in August, 1909 (Janensch, GTE field catalogue:
113). The quarry map (Fig. 11) is based on a field plan preserved in the GTE sketch book and a detailed list of skeletal elements assigned to Kentrosaurus (Hennig 1925: 228-229). Bones of Kentrosaurus aethiopicus are the most common skeletal elements of dinosaurs recovered from the Upper Saurian Bed at Site X, constituting more than $95 \%$ of the total dinosaur finds. The documented bone cluster is dominated by isolated hand and foot bones which formed a pavement on the quarry floor. Scattering and mixing of the skeletal elements is evident. Judging from the data by Hennig (1925: 228-229), the skeletal remains belong to at least 6 individuals
Tendaguru, Site $\mathbf{X}$ Upper Saurian Bed

Site plan and disposition of bones in the central part of the excavation

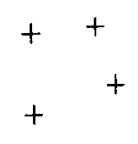

?+
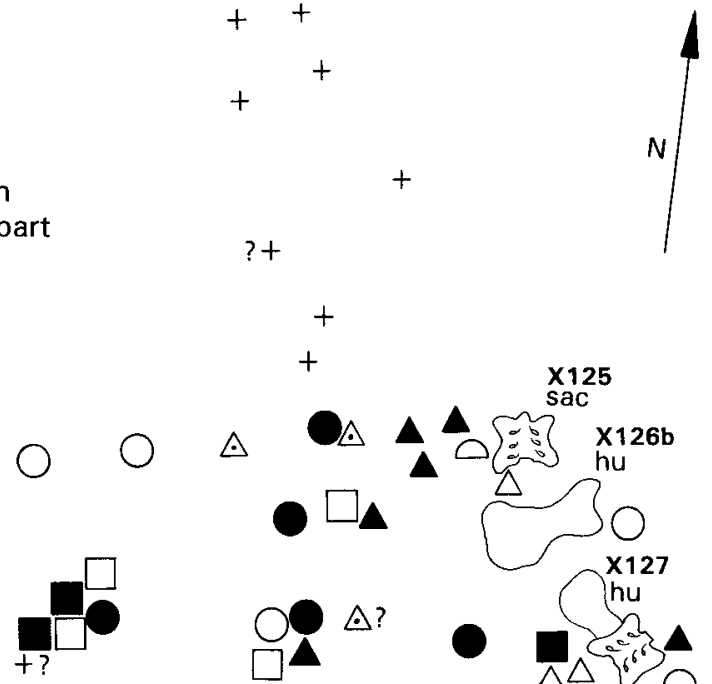

$\triangle$
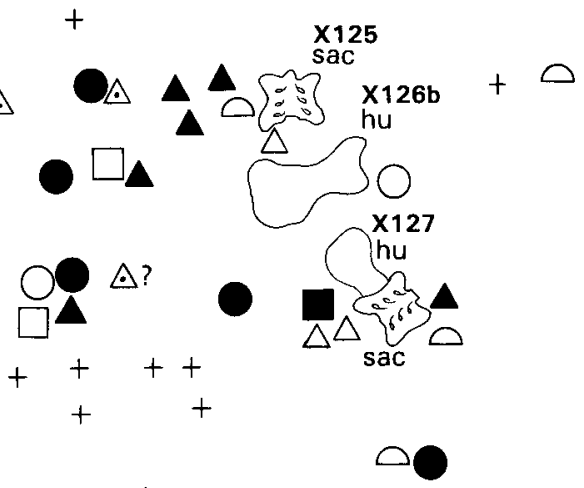

Kentrosaurus aethiopicus

$\square$ radiale+intermedium

U ulnare

$\triangle$ metacarpal

$\bigcirc$ phalange (manus)

$\Delta$ metatarsal

phalange (pes)

$+\quad$ indet. (manus or pes)

- cervical vertebra

D caudal vertebra

vertebra

fe femur

hu humerus

sac sacrum

tb tibia

Sauropoda indet.

caudal vertebra

do dorsal vertebra

approx. $1 \mathrm{~m}$

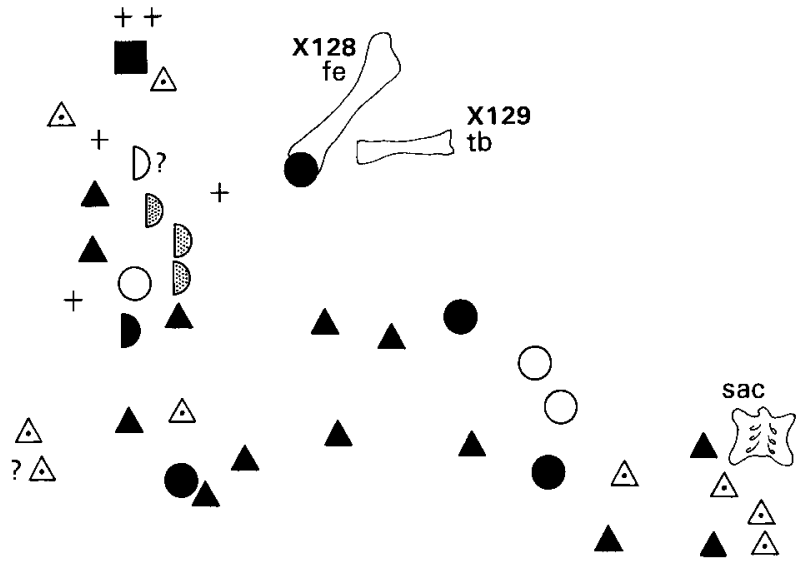

Fig. 11. Bone field in the central part of Tendaguru Site X. The accumulation is dominated by manus and pes elements of Kentrosaurus aethiopicus. Scattering is evident. Because of space limitation the catalogue numbers could only be shown for some bones. Redrawn after a field sketch from W. Janensch or E. Hennig 
of Kentrosaurus aethiopicus. Moreover, isolated sauropod vertebrae are also present.

The dominance of scattered and mixed hand and foot bones confirms the impression that there was substantial transport and sorting of bones prior to burial. However, the origin of the mass accumulation of kentrosaurian bones is difficult to explain owing to the lack of precise data. It is possible that carcasses of mired and drowned kentrosaurs floated or were washed away, whereas the hands and feet remained in the mud, which was subsequently reworked by currents or waves to form a pavement of bones. This interpretation would agree well with the taphonomic model proposed by Janensch (1914c). However, it is also possible that the hand and foot bones found at Site X were winnowed away from the decaying carcasses of Kentrosaurus aethiopicus and thus resulted from current sorting. Whatever happened, the place of burial is apparently not the place of death.

\subsection{Sites in the Transitional Sands above the Tri- gonia smeei Bed}

\subsubsection{Tendaguru Site $\mathbf{H}$}

Location: Site H is located $1.3 \mathrm{~km}$ northeast of Tendaguru Hill

Stratigraphy: Transitional Sands between the Trigonia smeei Bed and the base of the Upper Saurian Bed

Taxa: Barosaurus africanus,

Figure: 12 (colour figure on p. 43)

Reference: Janensch (1929a), GTE field catalogue: 11

Assemblage data

NISP: 24

MNI: 1

Number of taxa: 1

Designation: Multi-individual but single-taxon assemblage

Quarry data

Size of accumulation: approximately $14.00 \mathrm{~m}^{2}$

\section{Tendaguru, Site $\mathbf{H}$}

Transitional Sands between

Trigonia smeei-Bed

and Upper Saurian Bed

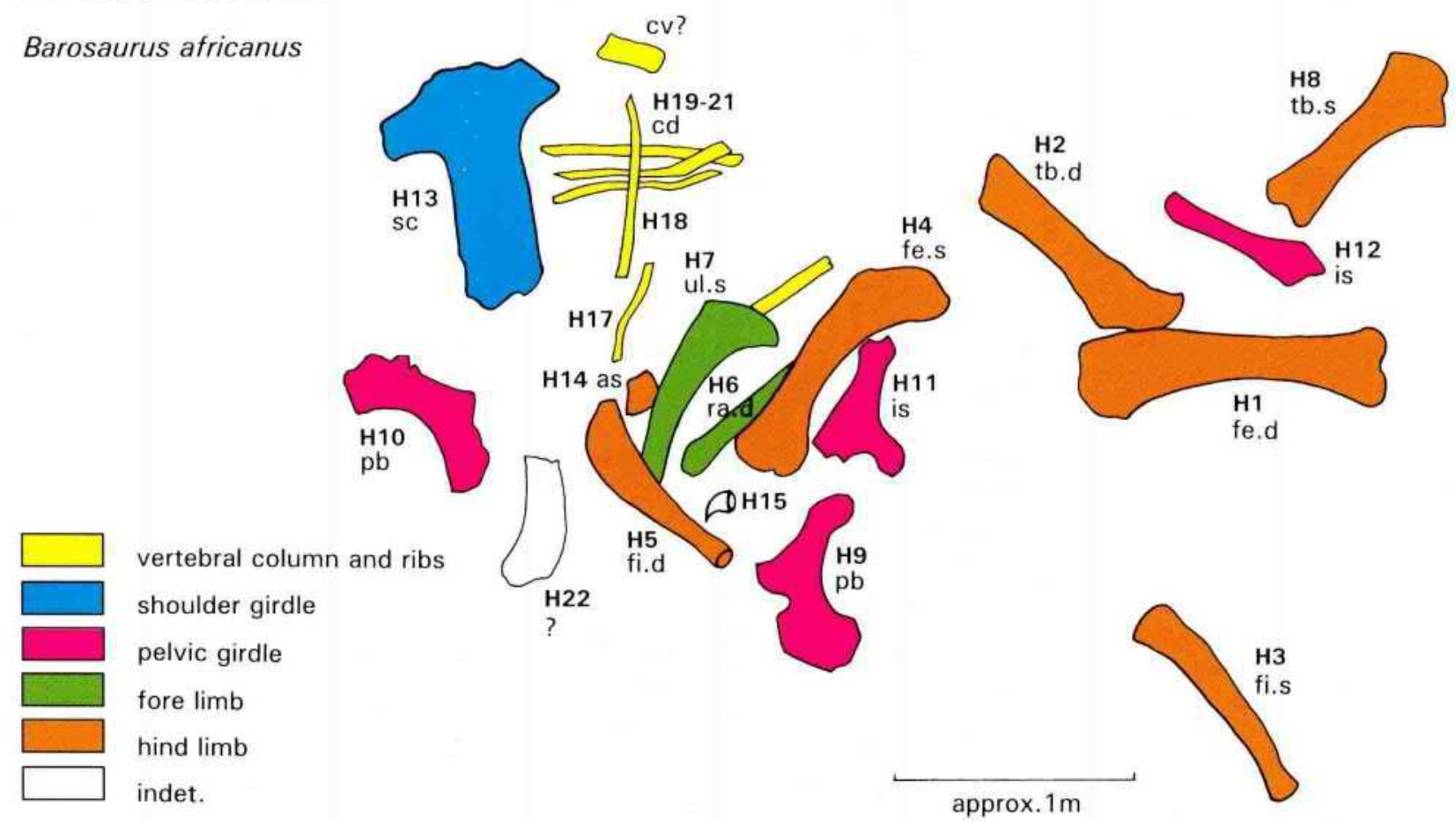

Fig. 12. Incomplete skeleton of Barosaurus africanus from Tendaguru Site H. The accumulation is dominated by limb bones and pelvic elements. Some limb bones rest on top of one another. The orientation of the map is not known. Redrawn after a field sketch from W. Janensch 
Density: approximately 1.71

\section{Modification data}

\section{Disarticulation stage: F}

Measurements: Right radius (H6): $700 \mathrm{~mm}$; left ulna (H7): $750 \mathrm{~mm}$; right femur (H1): $1200 \mathrm{~mm}$; left femur (H4): $1290 \mathrm{~m}$; right tibia (H2): $880 \mathrm{~mm}$; left fibula

(H3): $920 \mathrm{~mm}$; right fibula (H5): $960 \mathrm{~mm}$.

\section{Ontogenetic data: Unknown.}

Comments: The dig at Site $\mathrm{H}$ commenced in August, 1909 (GTE field catalogue: 11), and produced disarticulated and scattered bones of Barosaurus africanus, including ribs, scapula, ulna, radius, ischium, pubis, femur, tibia, and fibula (Janensch 1929a: 6). Some of these bones, such as the right femur (H1) and the right tibia $(\mathrm{H} 2)$, are still associated, but much of the material recovered is imperfect (e.g. scapula H13, pubes H10). The dominance of heavy long bones and the remarkable scarcity of small skeletal elements suggests that there was much post-mortem transportation of bones from the carcasses prior to burial. Because of the size differences between the two femora found $(\mathrm{H} 1$ : $1200 \mathrm{~mm} ; \mathrm{H} 4: 1290 \mathrm{~mm}$ ), it is concluded that the bone accumulation from Site $\mathrm{H}$ contains skeletal remains of at least two individuals of Brachiosaurus brancai.

In addition to these skeletal remains, Site $\mathrm{H}$ has yielded non-sauropod bones not documented in the field sketch, among them a coelurosaurian tibia and a metatarsal of Kentrosaurus aethiopi-
Tendaguru, Site IX Transitional Sands between

Trigonia smeei-Bed and Upper Saurian Bed
Site plan and disposition of bones

in the excavation

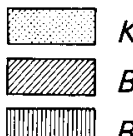

Kentrosaurus aethiopicus

Barosaurus africanus

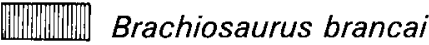

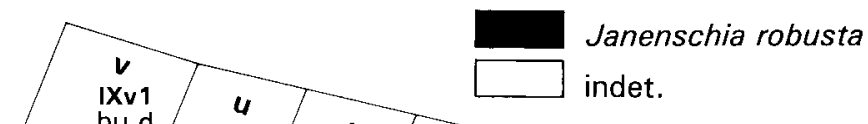

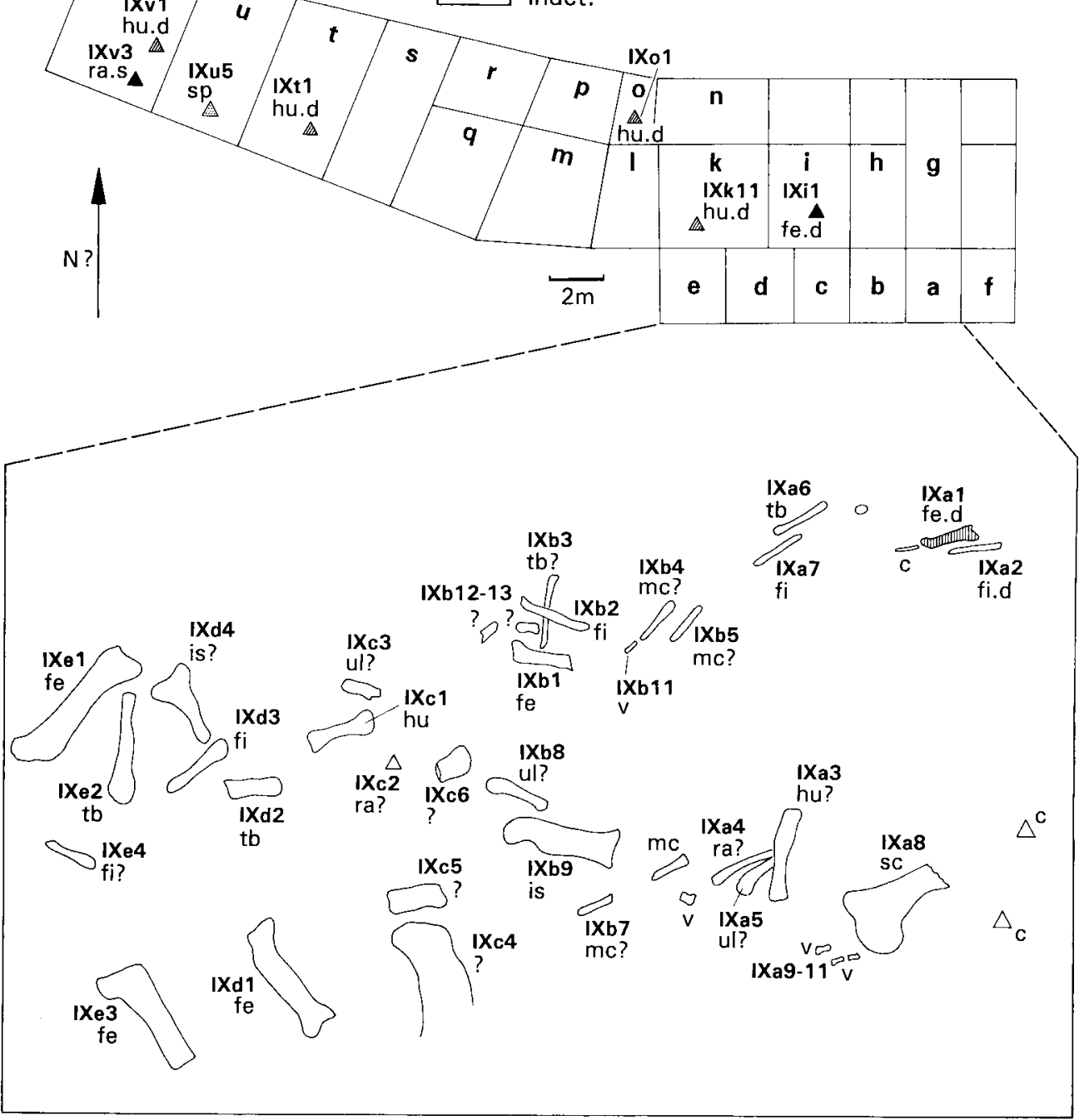

Fig. 13. Bone field from Tendaguru Site IX. The accumulation consists mainly of disarticulated limb bones from sauropods scattered over the quarry floor. Redrawn after a field sketch from W. Janensch 
cus (GTE field catalogue: 11). Their precise provenance is uncertain. Other discoveries from Site $\mathrm{H}$ include marine invertebrates (e.g., belemnites) indicating a marginal marine palaeoenvironment for the dinosaur-bearing Transitional Sands above the Trigonia smeei Bed, as formerly suggested by Janensch (1914c).

\subsubsection{Tendaguru Site IX}

Location: Site IX is situated about $1.4 \mathrm{~km}$ northeast of Tendaguru Hill.

Stratigraphy: Transitional Sands between the Trigonia smeei Bed and the base of the Upper Saurian Bed

Taxa: Barosaurus africanus, Brachiosaurus brancai, Janenschia robusta, Kentrosaurus aethiopicus

Figure: 13

Reference: Janensch (1914c), GTE field catalogue: 108-112.
Assemblage data

NISP: Unknown

MNI: Unknown

Number of taxa: (4)

Designation: Multi-individual, multi-taxon assemblage

Quarry data

Size of accumulation: The precise size of the excavation floor is not known. The exposed quarry floors $\mathrm{a}-\mathrm{f}$ measure, in total, roughly $13.0 \mathrm{~m}$ by $2.5 \mathrm{~m}$ (s. Fig. 13)

Density: Unknown

Modification data

Disarticulation stage: $O(N$ ?)

Measurements: Brachiosaurus brancai, length of a right femur (IXa1), $1180 \mathrm{~mm}$; length of left femur (IX1): $880 \mathrm{~mm}$; Barosaurus africanus, length of left humerus (IX94): $640 \mathrm{~mm}$; length of right humeri: $660 \mathrm{~mm}$ (IXk11), $730 \mathrm{~mm}$ (IXv1), 380 mm (IXx9).

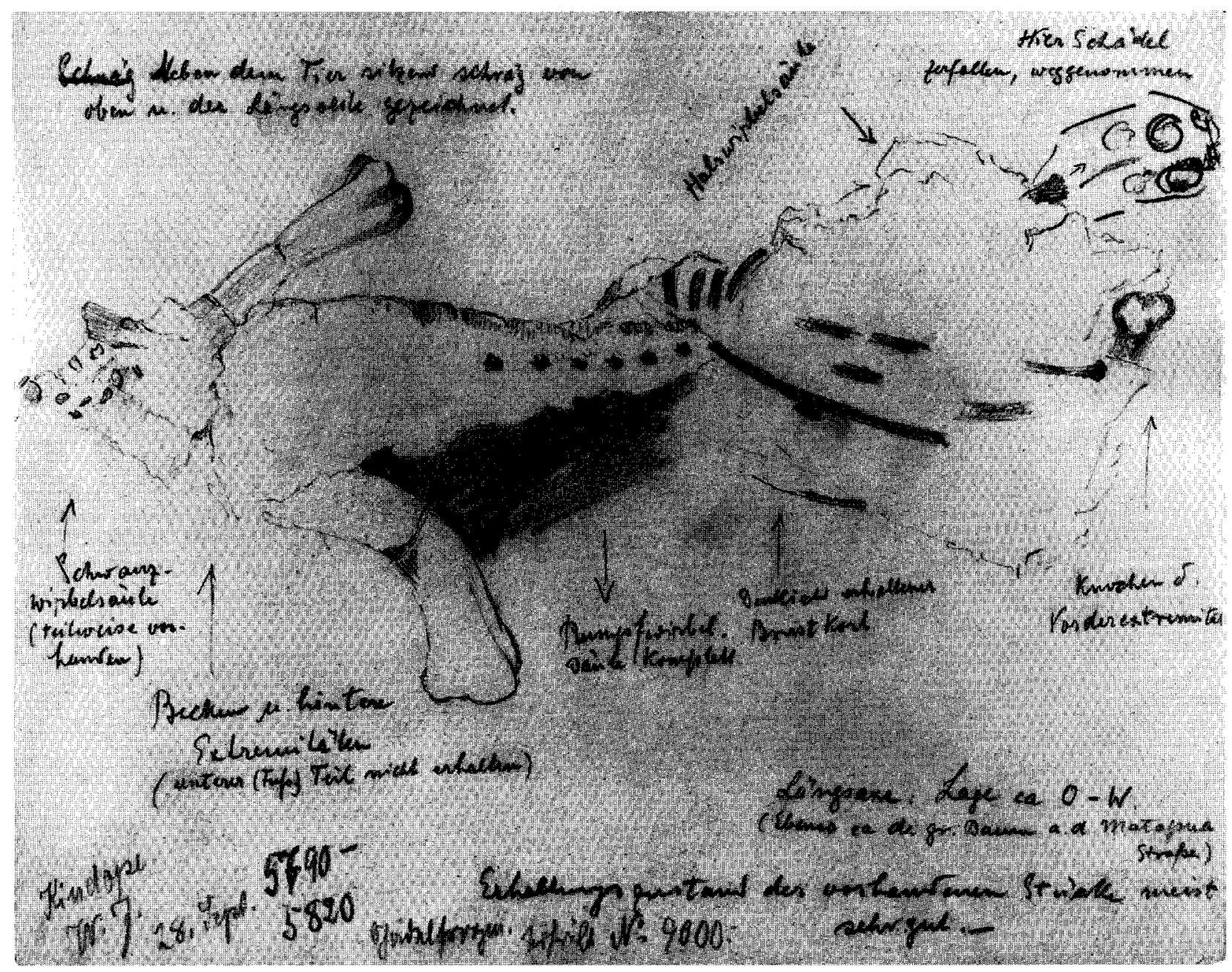

Fig. 14. Incomplete skeleton of Dryosaurus lettow-vorbecki from Tendaguru Site Jg (WJ). Original field sketch from I. Reck or H. Reck 
Ontogenetic data: According to Sander (1999, in press), humerus IX94 is from a juvenile individual of Barosaurus africanus, while femur IX1 is from an adult individual of Brachiosaurus brancai.

Comments: Excavations at Site IX commenced on August 17, 1909. About 150 individual bones of dinosaurs were collected from Site IX which was located between the Trigonia smeei-Bed and the Upper Saurian Bed (GTE field catalogue: 108), although only some of these were mapped (Fig. 13). Partial skeletons were not found, and the majority of bones were disarticulated and scattered over the excavation area, though some of them may have still been associated. Janensch (1914c: 44) reported that most of the bones were embedded horizontally and concentrated in a distinct bone-bearing layer. He also noted the dominance of bones from the appendicular skeleton (Janensch 1914c: 44). A closer study of the 130 identified bones from Site IX reveals that $85(=65,4 \%)$ are leg elements, including humeri, radii, ulnae, femora, tibiae, and fibulae (GTE field catalogue: 108-112). Other elements (e.g., vertebrae, pha- langes, ribs) are under-represented or completely missing (e.g., skull elements, lower jaws).

Some bones are well preserved, others in poor condition. The epiphyses of several limb bones are considerably worn due to rolling and abrasion by the embedding sands (Janensch 1914a, c), and there is no doubt that the skeletal remains were current modified. Moreover, the scattering and the state of preservation of the skeletal elements suggest a long period of time during which the bones were transported by waves and/or currents from the carcasses to the place of permanent burial.

Only a few catalogued limb bones have been identified taxonomically. Most of them apparently belong to sauropod dinosaurs. A minimum of four individuals of Barosaurus africanus are indicated by four right humeri. Skeletal remains of Brachiosaurus brancai, Janenschia robusta, and Kentrurosaurus aethiopicus are apparently less common than those of Barosaurus africanus, but precise specimen counts are not available. Belemnites have frequently been found at Site IX (GTE field catalogue: 108).

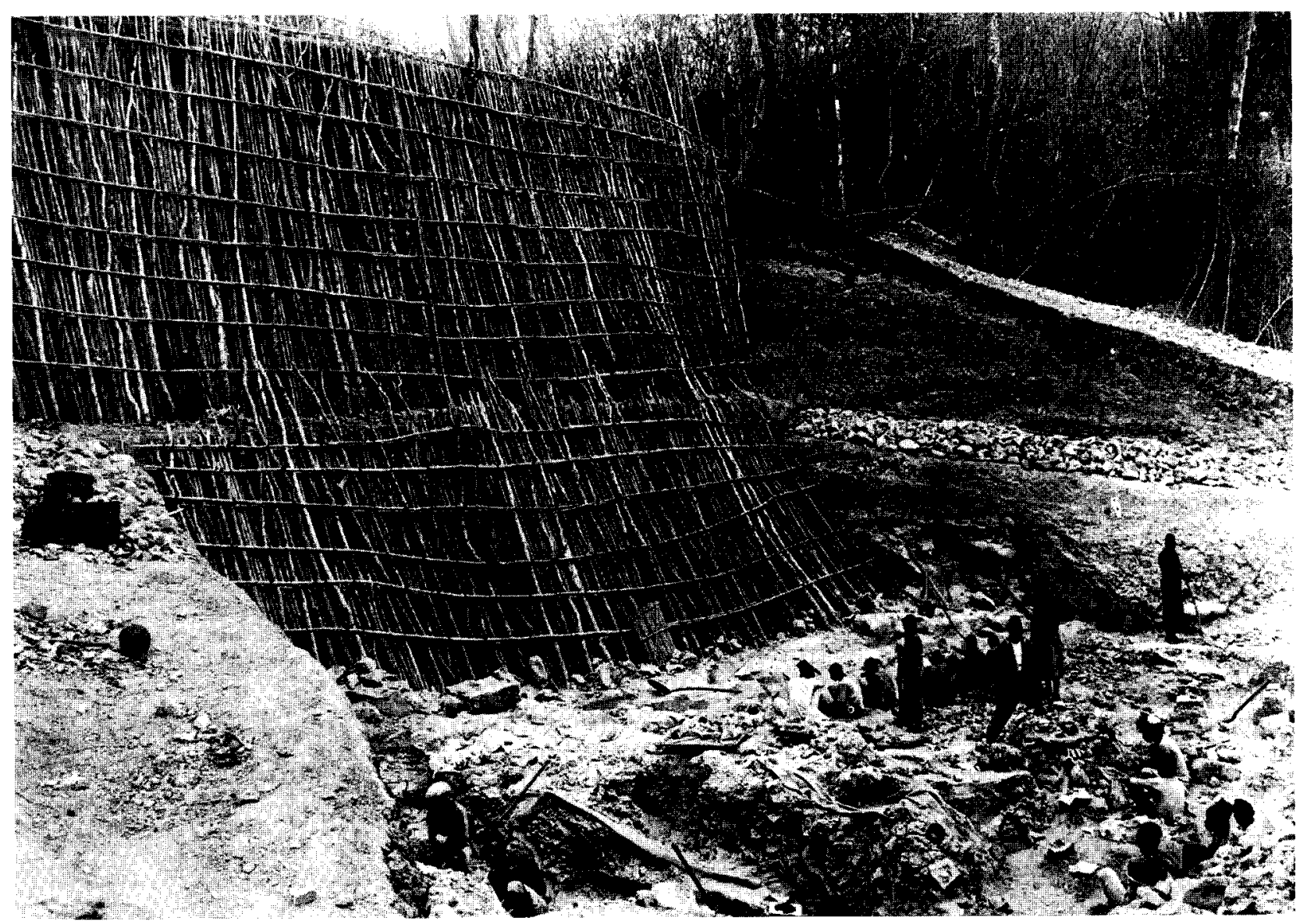

Fig. 15. Tendaguru Site S, the type locality of Brachiosaurus brancai. Photograph: W. Janensch 


\subsection{Sites in the Middle Saurian Bed}

\subsubsection{Tendaguru Site $\mathbf{J g}(=\mathbf{W J})$}

Location: Tendaguru Site $\mathrm{Jg}(=\mathrm{WJ})$ is located approximately $2.3 \mathrm{~km}$ north-north-west of Tendaguru Hill.

Stratigraphy: Middle Saurian Bed

Taxon: Dryosaurus lettow-vorbecki

Figure: 14

Reference: GTE sketchbook

Assemblage data

NISP: Unknown

MNI: 1

Number of taxa: 1

Designation: Single-individual, single-taxon assemblage

Quarry data

Size of accumulation: Unknown

Density: Unknown

Modification data

Measurements: Not available
Disarticulation stage: ? (complete or incomplete skeleton)

\section{Ontogenetic data: Unknown}

Comments: Excavations at Site Jg (WJ) commenced in 1910 and continued through the years 1911 and 1912 (Branca 1914; Janensch 1914c; GTE field catalogue: 73). Quarry $\mathrm{Jg}(\mathrm{WJ})$ is one of the richest dinosaur-bearing sites in the surroundings of Tendaguru Hill. It produced thousands of bones of the small ornithopod dinosaur Dryosaurus lettow-vorbecki (Janensch 1950c, 1955, 1961b). Judging from matrix kept in the Berlin Tendaguru collection, isolated vertebrae and limb bones of Dryosaurus lettow-vorbecki are the most common elements found in the Middle Saurian Bed at Site Jg (WJ). Skull fragments and teeth are fairly rare. Site $\mathrm{Jg}$ (WJ) has not only produced isolated bones but also partial and fairly complete skeletons (Fig. 14). Strings of vertebrae with closely associated chevrons also occur. The dryosaurs from Site Jg (WJ) are thought to have died close to the places where they were buried (Janensch 1914a, c).

\section{Tendaguru, Site $\mathbf{S}$}

Middle Saurian Bed

\section{Brachiosaurus brancai}

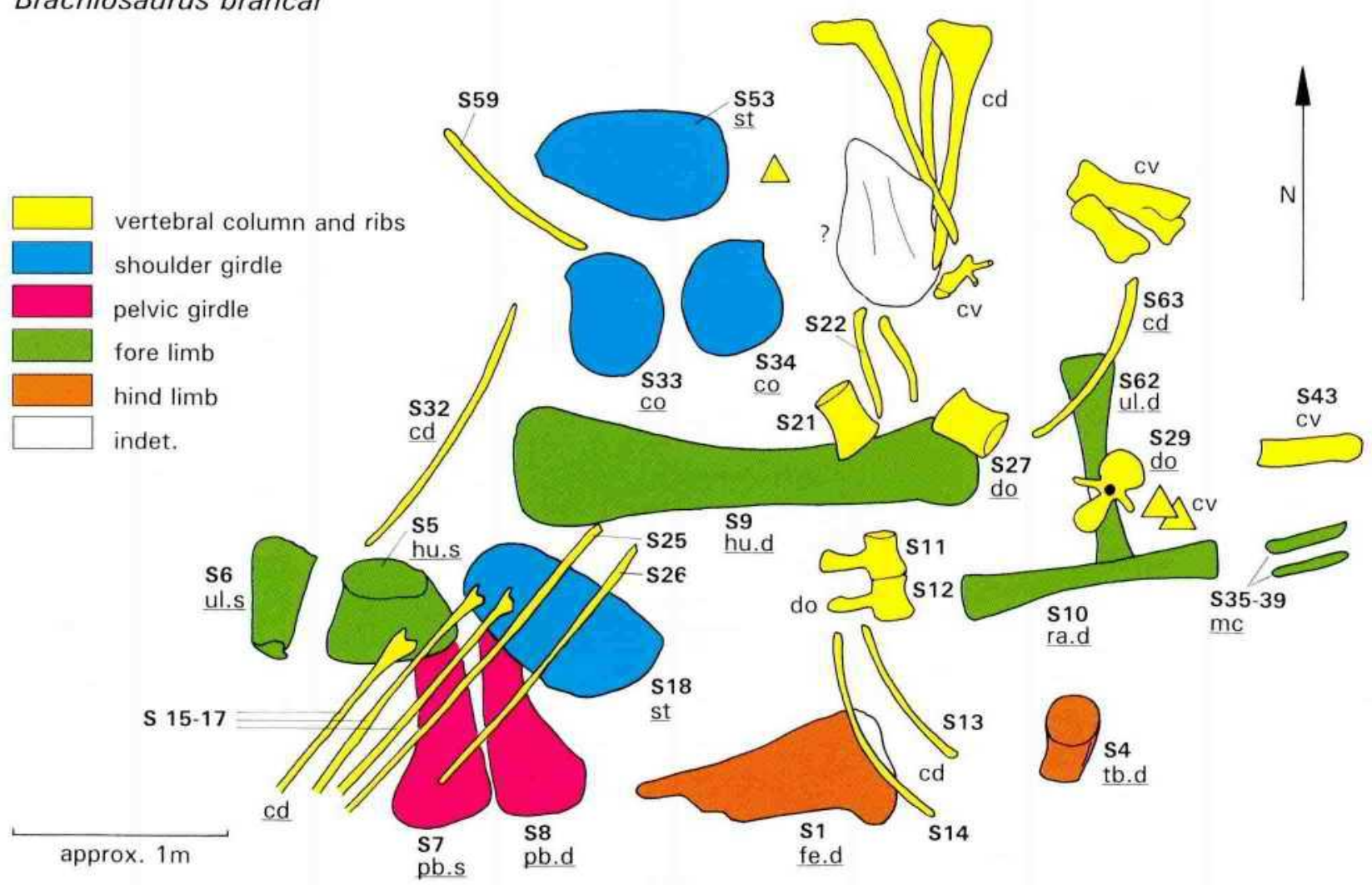

Fig. 16. Incomplete skeletons of Brachiosaus brancai from Tendaguru Site S. Anatomical identifications of skeleton SII are underlined. Elements of skeleton SI could not be indentified with certainty. The measured length of the humerus S9 $(213.0 \mathrm{~cm})$ was used to calculate the scale for the quarry map. Redrawn after a field sketch from W. Janensch 
A drawing of an in-situ skeleton of Dryosaurus lettow-vorbecki, preserved in the GTE sketchbook shows, a fairly complete skeleton recovered in 1912 (Fig. 14). An articulated skull seems to be present, and most of the vertebral column appears to be preserved in natural articulation, as do the dorsal ribs. The caudal vertebral column is partly preserved. From the fore limbs, nothing but the proximal section of a right humerus or ulna was documented. The left femur is spread slightly away from the trunk, and the proximal sections of both femora are apparently closely associated with the pelvic region. The lower legs were either not found or not documented in the field sketch. Unfortunately, the location of the documented skeleton of Dryosaurus lettow-vorbecki is not known.

\subsubsection{Tendaguru Site S}

Location: Site $\mathrm{S}$ is located approximately $1.0 \mathrm{~km}$ southsouthwest of Tendaguru Hill
Stratigraphy: Middle Saurian Bed

Taxon: Brachiosaurus brancai

Figures: 15, 16 (colour figure on p. 47) and 18 Reference: Janensch (1914a, c; 1929a, 1950a, b; 1961a), GTE field catalogue: $25-28$

Assemblage data

NISP: Not precisely known

MNI: 2

Number of taxa: 1

Designation: Multi-individual, single-taxon assemblage

Quarry data

Size of accumulation: ?

Density: ?

Modification data

Disarticulation stage: E (skeleton SII), L (skeleton S I)

Measurements: Skeleton SII, length of selected elements of the appendicular skeleton
Tendaguru, Site $\mathbf{Y}$

Middle Saurian Bed

Brachiosaurus brancai
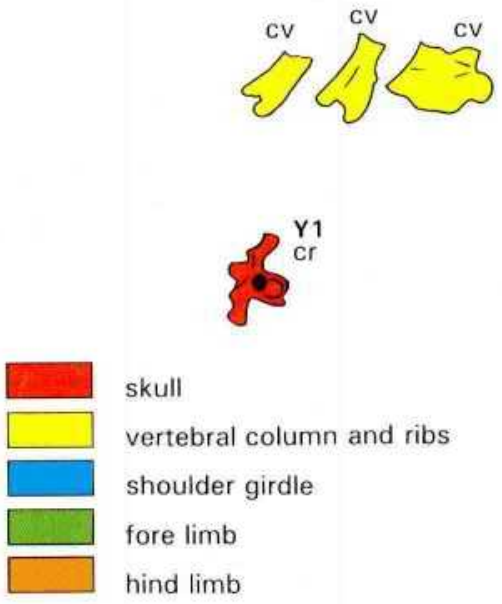

skull

vertebral column and ribs

shoulder girdle

fore limb

hind limb

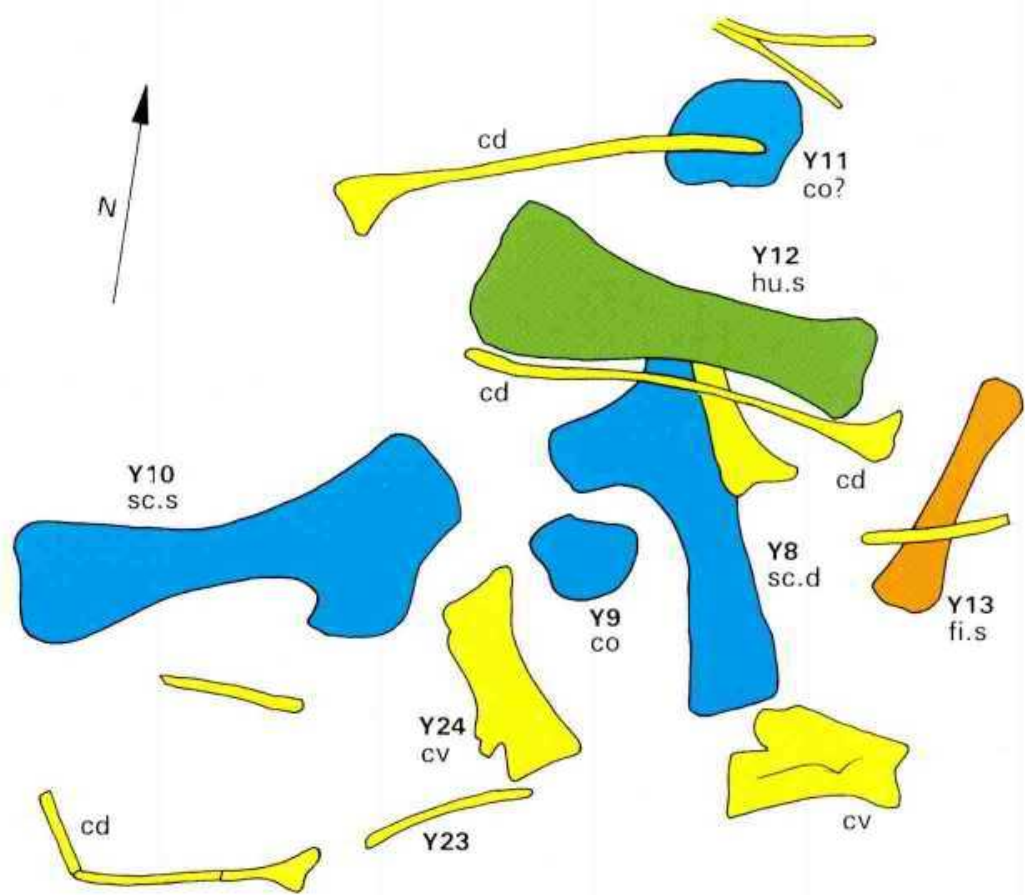

$\left\{\begin{array}{l}\text { Y27 } \\ \mathrm{ca}\end{array}\right.$

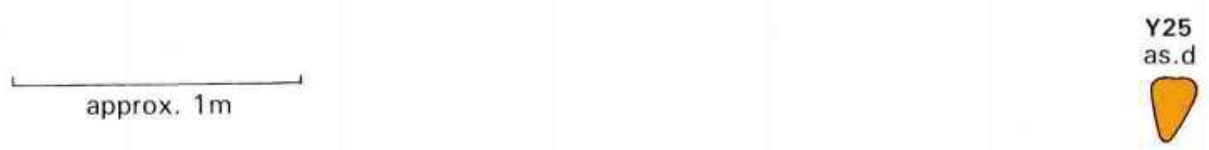

Fig. 17. Brachiosaurus brancai from Tendaguru Site Y. The incomplete skeleton consists of disarticulated elements from the anterior part of the body. The measured length of the scapula Y8 $(154.0 \mathrm{~cm})$ was used to calculate the scale for the quarry map. Redrawn after a field sketch from W. Janensch 
(Janensch 1961a): left sternal plate: $1100 \mathrm{~mm}$; right coracoid: ca. $840 \mathrm{~mm}$; right humerus: $2130 \mathrm{~mm}$; right radius: $1240 \mathrm{~mm}$; right Ulna: $1300 \mathrm{~mm}$; mc I dext.: $595 \mathrm{~mm}$; mc II dext: $635 \mathrm{~mm}$; mc III dext: $595 \mathrm{~mm}$; mc IV dext.: $570 \mathrm{~mm}$; mc V dext.: $490 \mathrm{~mm}$; right femur: ca. $1960 \mathrm{~mm}$, right fibula: $1190 \mathrm{~mm}$.

Ontogenetic data: Judging from solitary limb bones that are at least one tenth larger than those of skeleton SII, it could be concluded that the SII specimen was not yet fully grown (Janensch 1938).

Comments: The dig commenced on October 11, 1909 and Tendaguru Site S was worked by the German Tendaguru until 1911 (Janensch 1914a). Site S is the type locality for Brachiosaurus brancai and remains of two individuals were found. Skeleton SI, the type specimen of
Brachiosaurus brancai, is a partial skeleton, comprising the skull, six cervical vertebrae and (?) dorsals (Janensch 1929a: 8). Specimen SII which is larger than SI, is an incomplete skeleton of Brachiosaurus brancai (Janensch 1914a, c; 1929a; 1950a, b; 1961a), including skull bones, a nearly complete presacral vertebral column (11 cervical and 11 dorsal vertebrae), cervical and dorsal ribs, most of the anterior appendicular skeleton (left scapula, coracoids, sternals, right anterior limb, left humerus, ulna, and radius), parts of the pelvic girdle (e.g. both pubes bones), and incompletely preserved hind limbs (e.g., imperfect right femur, right tibia and fibula, and foot bones). The sacrum and the caudal series were already missing when the specimen was discovered, most likely due to erosion (Janensch 1914c).

Janensch $(1914 a, c)$ reported that the humerus and a tibia of the SII individual were found in

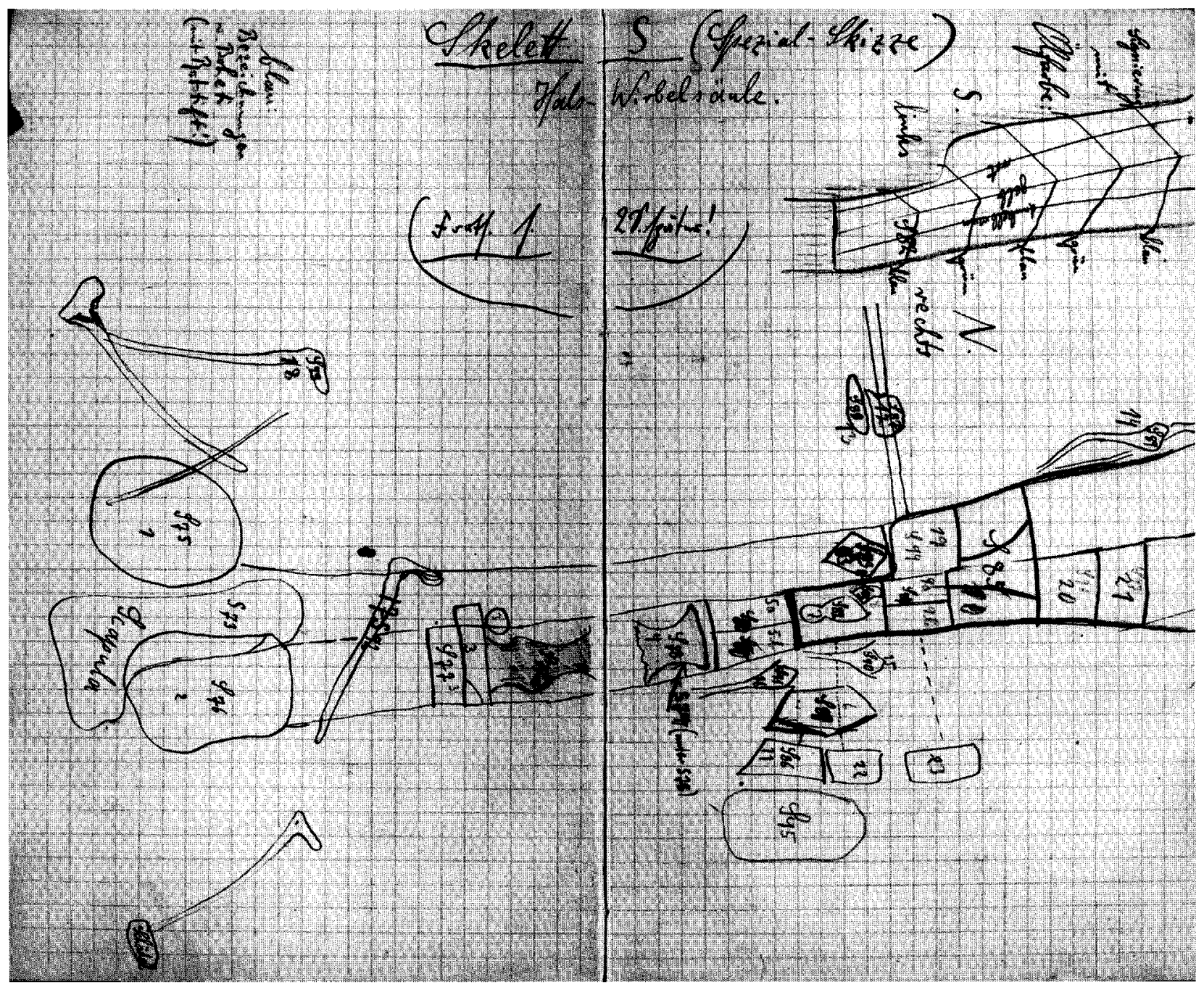

Fig. 18. Brachiosaurus brancai from Tendaguru Site S. The articulated series of vertebrae from skeleton SII includes anterior dorsals and cervical vertebrae. Original field sketch from $\mathrm{W}$. Janensch. The skeletal elements in the figure are tentatively identified as follows: S73 - left scapula; S76 - dorsal vertebra 2; S77 - dorsal vertebra 1; S78 - cervical vertebra 13; S82-S87 (? S80, ? S88) - cervical vertebra 12; S89-S91 - cervical ribs; S92-S93 - dorsal ribs; S96-S97 (? 94) - cervical vertebra 11 
an upright position, suggesting that the animal mired in soft mud. The proximal section of this humerus shows distinct traces of abrasion, indicating that the skeleton was affected by moving water prior to burial (Janensch 1914c). The bones of the right fore limb were found in natural order, but not articulated, and several bones (e.g., coracoids, right humerus, radius ulna) were embedded in a horizontal position (Fig. 16). The distal part of the left anterior limb was absent upon discovery, possibly due to post-depositional erosion (Janensch 1914a, c).

Sections of the reasonably complete presacral vertebral column of specimen SII are roughly documented in two separate field sketches, partly in pencil, partly in ink. One of these two field sketches is reproduced in the present account (Fig. 18). According to Janensch (1950a: 33 ), the anterior section of the vertebral column, including presacral vertebrae 3 to 15 , were found in natural order. The three anteriormost presacral vertebrae (3-5) are well preserved and do not show signs of abrasion, while the remaining presacral vertebrae $(6-15)$ are articulated and display close, bone-to-bone contact, except for presacral vertebra 8 which was slightly dislocated. The dorsal parts of presacral vertebrae 9 to 15 are missing, possibly due to attrition by the fine sands in which the remains were embedded (Janensch 1950a). The string of presacral vertebrae (3 to 15 ) was recovered from a massive limy sandstone bed, unike presacral vertebrae 17 to 24 which were found together with other bones from skeleton SII in marls below the limy sandstone bed (Janensch 1950a: 33). The majority of these posterior presacral vertebrae were disarticulated, except for vertebrae 23 and 24 which were found in bone to bone contact (Janensch 1950a: 33).

The sediments exposed at the place of burial show that low-energy dinosaur-bearing marls passed into higher-energy sandy deposits. The shape of most bones recovered from Site $\mathrm{S}$ has not been substantially changed by taphonomic or diagenetic processes. The taphonomic evidence obtained from skeleton SII suggests carcass maceration and decay of a mired individual of $\mathrm{Bra}$ chiosaurus brancai prior to burial (Janensch 1914c).

\subsubsection{Tendaguru Site $\mathbf{Y}$}

Location: Site $\mathrm{Y}$ is located about $3.1 \mathrm{~km}$ north of Tendaguru Hill.
Stratigraphy: Middle Saurian Bed

Taxon: Brachiosaurus brancai

Figure: 17 (colour figure on p. 48)

Reference: Janensch (1929a), GTE field catalogue: 37

Assemblage data

NISP: 23

\section{MNI: 1}

Number of taxa: 1 (2)

Designation: Single-individual, single-taxon assemblage

Quarry data

Size of accumulation: approximately $21.00 \mathrm{~m}^{2}$

Density: approximately 1.1

Modification data

Measurements: length of a left scapula: $1540 \mathrm{~cm}$; length of a right astragalus: $160 \mathrm{~mm}$ (Janensch 1961a).

Disarticulation stage: $F$

Ontogenetic data: The remains of Brachiosaurus brancai recovered from Site $\mathrm{Y}$ are from a medium-sized individual (Janensch 1950a: 33).

Comments: The excavations at Site Y commenced in 1910 (GTE field catalogue: 37). The bone accumulation from Site $Y$ represents an incomplete skeleton, dominated by bones from the anterior body half. From the posterior skeleton only a fibula was found. Site $\mathrm{Y}$ has yielded a monospecific bone accumulation assigned to $\mathrm{Bra}$ chiosaurus brancai. All bones documented are disarticulated. Janensch (1929a: 8) noted a braincase, eight cervicals, ribs, scapula, coracoid, humerus, and a dorsal vertebra. The skeleton is apparently current-modified, with a scapula resting next to a humerus and dorsal ribs. The cervical vertebrae are approximately in anatomical order (Janensch 1929a: 8), and the braincase lies close to them. The majority of the long bones were embedded with their long axes oriented west to east (e.g, right scapula, left humerus, dorsal ribs). Only a few elongated bones (e.g., left scapula, left fibula) are approximately oriented north to south. Some bones were embedded on top of one another (e.g., right scapula, left humerus). The taxonomic allocation of a small elongate caudal vertebra that was found south of the left scapula is far from clear. 


\subsubsection{Tendaguru Site m}

Location: This site was situated close to Kindope, about $3.2 \mathrm{~km}$ north of Tendaguru Hill.

Stratigraphy: Middle Saurian Bed

Tax on: Dicraeosaurus hansemanni

Figure: 19

Reference: Janensch (1914a; 1929a, b, 1936, 1961a), GTE field catalogue

Assemblage data

NISP: Unknown

MNI: 1

Number of taxa: One-individual assemblage Designation: Single individual assemblage, single-taxon assemblage

Quarry data

Size of accumulation: Unknown

Density: Unknown

Modification data

Measurements: The length of the preserved pelvic elements and limb bones is as follows (Janensch 1961a): right ilium: $840 \mathrm{~mm}$; right pubis: $795 \mathrm{~mm}$; right ischium: $750 \mathrm{~mm}$; right fe- mur (m5): $1220 \mathrm{~mm}$; left tibia (m1): $760 \mathrm{~mm}$; left fibula (m3): $800 \mathrm{~mm}$, left astragalus: $165 \mathrm{~mm}$

Disarticulation stage: $\mathrm{E}$

Ontogenetic data: Unknown

Comments: One of the most important discoveries of the 1910 field season was the type specimen of Dicraeosaurus hansemanni, recovered from the Middle Saurian Bed at Site m near Kindope (Janensch 1914a). Unfortunately, a quarry plan is not available. The more important taphonomic data published by Janensch (1929a, b) are briefly summarized below.

The skeleton is incomplete, but remarkably well preserved. Much was found in natural articulation. The skull, proatlas, and axis have not been not recorded. A series of vertebrae ranging from cervical 2 to caudal 19 lay in natural order. Only the anterior end of the tail was recovered; the posterior tail section beyond caudal 19 was lost prior to discovery. The preserved part of the tail is slightly recurved (Janensch 1929b: 41). Ilium, pubis, parts of the ischium, and the femur of the right body side were discovered in situ. The left femur was found close to the sacrum. The sternal plates, coracoids, scapulae, and ante-

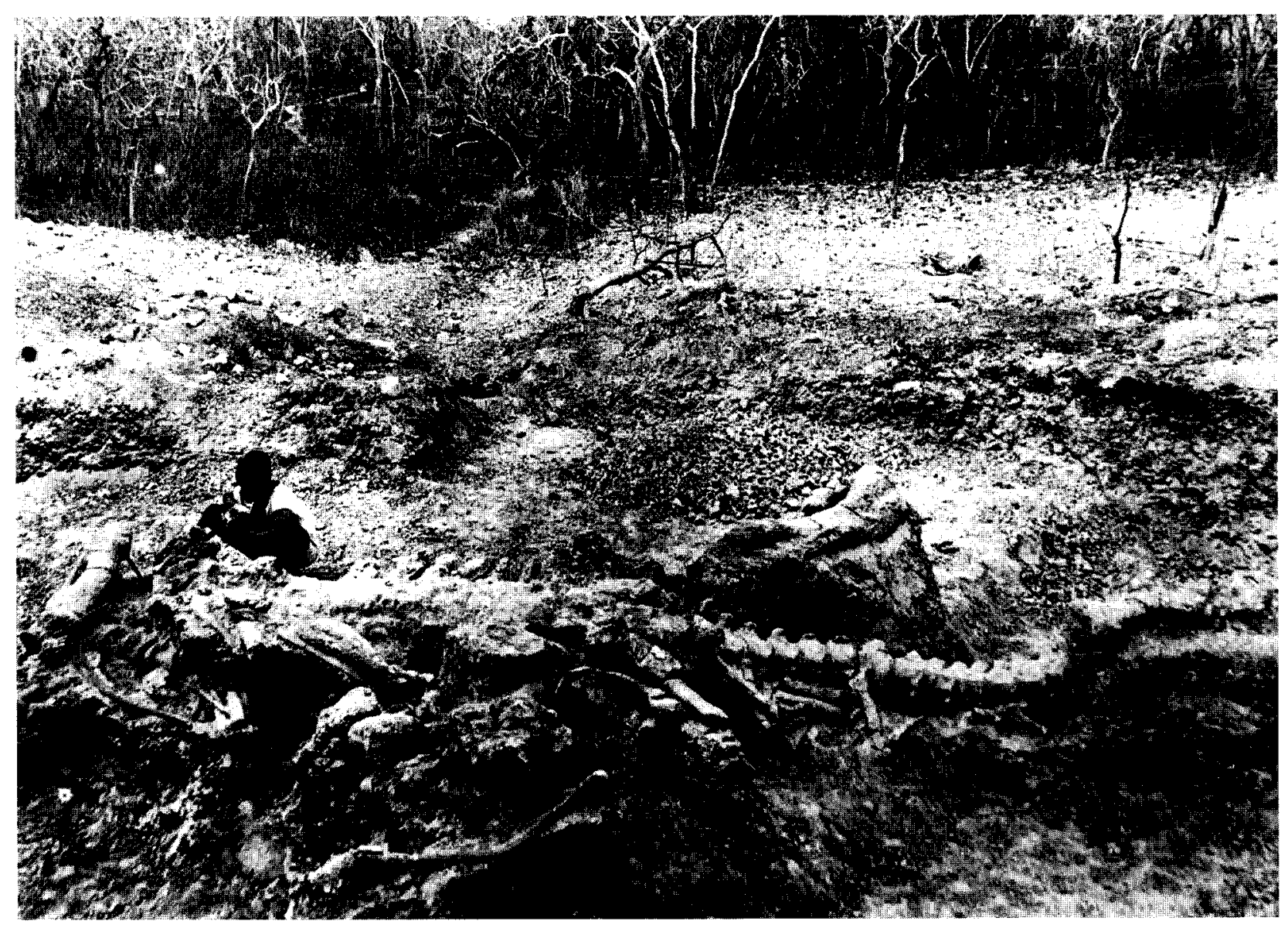

Fig. 19. Type specimen of Dicraeosaurus hansemanni from Tendaguru Site m. Photograph: W. Janensch 
rior limbs have not been recorded. Except for the femora, the hind limbs are represented by the articulated left lower leg (tibia, fibula, and astragalus), found just above the posterior section of the neck. Feet are not recorded. The well-preserved right dorsal ribs are still articulated with the dorsals. The left dorsal ribs are incompletely preserved and scattered, but close to the skeleton. Some vertebrae suffered considerable damage: nearly all the left diapophyses are missing in the section ranging from dorsal 13 to caudal 1 , and of the posterior dorsals, the left parapophyses, the left neurapophyses and the centra are water worn. Three caudals were found at some distance from the skeleton. Their association with the preserved caudal series of skeleton $\mathrm{m}$ is uncertain.

According to Janensch (1929b: 41), the carcass floated quite a long distance in quiet water before it came to rest on its right side. Afterwards, the anterior section of the neck was flexed ventrally, rotated and became separated from the posterior cervicals. Subsequently, this section came to rest in an oblique position adjacent to the carcass prior to burial. Afterwards, exposed parts of the skeleton, including the left dorsal and sacral diapophyses, the left rib cage, the left pelvic girdle, and perhaps the left hind limb were abraded, truncated and dispersed close to the skeleton. The skull, most of the appendicular skeleton (e.g., sternal plates, anterior limbs, right lower leg, both feet, and ? left hind limb) and the posterior section of the tail were probably lost during post-mortem transport from the place of death to the site of burial.

\section{Discussion: taphonomic patterns in Tendaguru dinosaurs}

\subsection{Occurrence of bones}

Most field sketches preserved in the achives of the IPHB document bone accumulations for the sauropod dinosaurs Brachiosaurus, Barosaurus, Dicraeosaurus, and Janenschia. Quarry plans documenting bone assemblages for ornithischians (Dryosaurus, Kentrosaurus) are rare. Nothing can be said about the original position of skeletal remains of theropods (e.g., Elaphrosaurus) due to the lack of field sketches for these taxa.

The documented skeletal remains recovered from quarries in the vicinity of Tendaguru Hill represent a broad spectum of disarticulation and disassociation. They belong to a sequence of disarticulation stages recognized in the Tendaguru Beds (Tab. 2), including (1) incomplete skeletons with bones partially articulated (e.g., Dicraeosaurus hansemanni, Site m; Brachiosaurus brancai, Site S), (2) complete or incomplete partial skeletons (e.g. Janenschia robusta, Site P), (3) assemblages of predominantly disarticulated skeletal elements concentrated in bone fields (e.g. Barosaurus africanus, Site C; Kentrosaurus aethiopicus, Site X), and (4) solitary bones. Virtually complete dinosaur skeletons have not been found in the Tendaguru Beds so far (Hennig 1912b). Partial skeletons show a similar broad spectrum of disarticulation stages as incomplete skeletons (Table 2), but both may reflect different taphonomic histories. A partial skeleton, for example, may not only result from gradual "in-situ" carcass decay at the site of death or final deposition but also from early post-mortem truncation and pre-burial transport of carcass parts from the site of death or from the original location of carcass deposition.

Mono- and multispecific assemblages of dinosaurian skeletal elements have been recognized. Monospecific assemblages, for instance, are documented for Barosaurus africanus (e.g., Site C), Brachiosaurus brancai (e.g., Site S), Dicraeosaurus hansemanni (Site m), and Dryosaurus lettow-vorbecki (Site $\mathrm{Jg}=\mathrm{WJ})$. These assemblages are usually represented by incomplete or partial skeletons, and they are mainly known from the Middle Saurian Bed (e.g., Sites $m$ and S) and the Upper Saurian Bed (Sites C, D, N). Multispecific assemblages have been documented, for instance, from Site ab (Barosaurus africanus, Brachiosaurus brancai, Dicraeosaurus sattleri), and Sites IX and X (Barosaurus africanus, Brachiosaurus brancai, Janenschia robusta, Kentrosaurus aethiopicus). Multispecific assemblages are typical of the Transitional Sands above the Trigonia smeei Bed (Site IX), but have also been documented in the Upper Saurian Bed (e.g., Sites ab, $\mathrm{X})$.

Calculations of the MIN's reveals that singleindividual assemblages (e.g., Barosaurus africanus, Sites C; Brachiosaurus brancai, Sites D, M; Dicraeosaurus sattleri, Site $\mathrm{O}$ ) and multi-individual assemblages (e.g., Brachiosaurus brancai, Site S; Janenschia robusta, Site P) both occur. The Middle and Upper Saurian Beds have yielded both single-individual assemblages (e.g., Dicraeosaurus hansemanni, Middle Saurian Bed, Site m; Barosaurus africanus, Upper Saurian Bed, Site k) and multi-individual assemblages 
(Brachiosaurus brancai, Middle Saurian Bed, Site S; Janenschia robusta, Upper Saurian Bed, Site $\mathrm{P}$ ). The documented bone assemblages from the Transitional Sands above the Trigonia smeei Bed are multi-individual in nature (e.g. Barosaurus africanus, Site $\mathrm{H}$; Barosaurus africanus, Brachiosaurus brancai, Janenschia robusta, Kentrosaurus aethiopicus, Site IX). Single-individual assemblages are more frequently documented than multi-individual assemblages.

The documented multi-individual assemblages consisting of incomplete or partial skeletons of sauropods are always monospecific. Examples include the skeletons SI and SII of Brachiosaurus brancai from the Middle Saurian Bed Site S, and the partial skeletons I-IV of Janenschia robusta from Upper Saurian Bed Site P. In addition, Janensch (1929a: 9) reported two individuals of $D i$ craeosaurus hansemanni from the Middle Saurian Bed at Site dd.

The Middle Saurian Bed has yielded the best preserved skeletons from Tendaguru, some of which, notably those of Brachiosaurus brancai (Site S) and Dicraeosaurus hansemanni (Site m), are on display in the Museum of Natural History of Humboldt University, Berlin. An unpublished field sketch of Site Jg (WJ) indicates that reasonably complete skeletons of ornithischians (Dryosaurus lettow-vorbecki) were also found. Moreover, the Middle Saurian Bed has produced enormous concentrations of disarticulated skeletal remains of smaller ornithischians such as Kentrosaurus aethiopicus from Sites $\mathrm{St}, \mathrm{He}$ and X (Janensch 1914c, Hennig 1915, 1916, 1925) and Dryosaurus lettow-vorbecki from Site Jg (Janensch 1914c, 1955, 1961b; Galton 1981).

Reported recoveries of theropod dinosaurs include several disarticulated and scattered skeletal elements from Tendaguru Site dd that are apparently derived from a single skeleton of Elaphrosaurus bambergi (Janensch 1925b: 7; Galton 1982). Included in this collection, but undocumented in field sketches, are 17 presacral vertebrae, 18 caudal vertebrae, a chevron bone, two imperfect ribs, both scapulae and coracoidea, right humerus, two metacarpals, sacrum, left pubis, two ilia and ischia, left femur, tibia, fibula, astragalus, and two phalanges (Janensch 1925b: 7, 1929c: 280). In addition, several localities of the Middle Saurian Bed, such as the collecting sites St and H (Janensch 1920, 1925b), produced isolated limb bones and teeth.

Samples from the Middle Saurian Bed housed in the Berlin Tendaguru collection confirm the impression that skeletal remains of Dryosaurus lettow-vorbecki are extraordinarily abundant at Site Jg (WJ). Here, the matrix is dominated by vertebrae and limb bones, some partly articulated, and some partly disarticulated. Isolated bones are also very common. By contrast, skull bones and teeth are very rare, as are small hand and foot bones. It should be mentioned that bones from Dryosaurus lettow-vorbecki (Site Jg) and sauropod caudal vertebrae (Site dd) encrusted with calcite have repeatedly been found. These calcite rinds, measuring $2 \mathrm{~mm}$ to $5 \mathrm{~mm}$ in thickness, are infillings of post burial shrinking cracks. Janensch (1925b: 7) also reported calcareous rinds that covered bones of Elaphrosaurus bambergi recovered from Tendaguru Site dd.

Skull material from sauropods is extremely rare, although the Middle Saurian Bed at Site $t$ has yielded a disarticulated complete skull of Brachiosaurus brancai with 56 teeth in its jaws, and Tendaguru site dd, for instance, produced braincases of Dicraeosaurus hansemanni and Barosaurus africanus (Janensch 1935).

Janensch (1914c) reported water worn bones of Brachiosaurus brancai (skeleton SII) from Site $\mathrm{S}$ as well from Dicraeosaurus hansemanni from Site $m$. The material from the Middle Saurian Bed is evidently current modified. Most skeletal elements were apparently carried away from carcasses, skeletons or partial skeletons, possibly by currents or wave action.

Bone accumulations from the Transitional Sands above the Trigonia smeei Bed are dominated by disarticulated sauropod dinosaur limb bones. Much of the material is in poor condition, confirming Janensch's (1914a, c) interpretation that there was much destruction, transportation, and sorting of bones. Abraded epiphyses are thought to be evidence of water action (Janensch 1914a, c; 1961a). Most of the bones rest horizontally next to one another, possibly due to wave action or wave-induced currents (Janensch $1914 \mathrm{a}, \mathrm{c})$. There is no doubt, that this material underwent sorting through a broad spectrum of post-mortem processes prior to burial.

Russell et al. (1980: 172) reported the dominance of Barosaurus africanus in the Transitionals Sands above and below the Trigonia smeei Bed and noted "a significantly higher number of elements from the left side" of the barosaur body. From Site Ki, Transitional Sands below the Trigonia smeei Bed, Hennig (1925: 247) mentioned a complete but somewhat disarticulated left lower leg of Kentrosaurus aethiopicus, including the tibia, fibula, and bones of the pes. 
Most quarry maps from the Upper Saurian Bed primarily document disarticulated skeletal materials from sauropods (e.g., Brachiosaurus brancai, Sites D, N, cc; Dicraeosaurus sattleri, Site O). Incomplete skeletons (e.g., Barosaurus africanus, Site k) and partial skeletons (e.g., Janenschia robusta, Site P) also occur, with both partly articulated, and partly disarticulated bones. As mentioned above, most of the bone accumulations appear to represent single-individual assemblages, although, multi-individual assemblages have also been recognized. Janensch (1922, 1961a) reported an articulated manus skeleton of Janenschia robusta from Site Nr. 5 and Brachiosaurus brancai from Site R, as well as two articulated pes skeletons of Barosaurus africanus from Sites XIII and 28, suggesting that sauropod dinosaurs became mired in soft mud (Janensch 1914c: 249). Fore- and hindlimb skeletons (e.g. Janenschia robusta from Site P) and strings of vertebrae (e.g. Barosaurus africanus from Site C) and accumulations of disarticulated bones (e.g. Barosaurus africanus, Dicraeosaurus sattleri, and ? Brachiosaurus brancai from Site ab) show that the carcasses underwent considerable pre-burial decay, as formerly suggested by Janensch (1914c, 1961a) and Hennig (1925).

The Upper Saurian Bed produced mass accumulations of skeletal elements of the ornithischian Kentrosaurus aethiopicus (Hennig 1925). A bone field uncovered at Site X, for instance, consists mainly of isolated and jumbled elements from the manus and pes (Janensch 1914c, Hennig 1925) reflecting a secondary concentration of dinosaurian material (Fig. 10). Hennig (1915: 244; 1925: 247) reported an incomplete skeleton of Kentrosaurus aethiopicus from Site bb which is close to the top of the Upper Saurian Bed. The skeleton includes a left scapula and coracoid, imperfect left pubis, fragmentary ischium, both femora, a caudal vertebra, and fragments of ribs and vertebrae (Hennig 1925: 247). Field sketches are not available, the stage of disarticulation is unknown.

Isolated bones and teeth indicate the presence of theropod dinosaurs in the Upper Saurian Bed, among them Ceratosaurus, Allosaurus and Elaphrosaurus (Janensch 1925b, 1929c). Bones are very rare, and teeth are more frequently preserved. According to Janensch (1925b: 61), a left quadratum, left fibula, and three imperfect caudal vertebrae recovered from Site $\mathrm{Mw}$ are assignable to one individual of Ceratosaurus (?) roechlingi.

\subsection{Bone representation}

The great majority of sauropod bone acculumations either documented in the field sketches or listed by Janensch (1929a, GTE field catalogue) are incomplete skeletons or partial skeletons. The field sketches examined in this account and data given by Janensch (1929a) show that some skeletal elements are more frequently recorded than others. Skull remains for instance, are extremely rare, whereas appendicular skeletal elements usually dominate the bone assemblages examined. This raises the question, to what extent certain skeletal elements better survived the taphonomical filters than others. This question is difficult to answer, however, because no firsthand data are available. According to the records of sites, not all bones found have been documented in field sketches. In addition, poorly preserved bones were not collected at some sites (Janensch, GTE field catalogue). In order to minimize the affects caused by collector preferences, individual bone representation diagrams were replaced in the present account by a bodypart representation diagram. This diagram (Fig. 20) reflects only "summarily" the presence of body parts recognized in skeletons, but does not consider the abundance of individual skeletal elements within the distinguished body parts.

The analysis of incomplete skeletons and partial skeletons of Tendaguru sauropods from about 30 sites, partly documented in the field sketches, partly listed by Janensch (1929a) led to the following conclusions (Fig. 20): (1) As expected, the paired elements of the appendicular skeleton dominate the fossil record of Tendaguru sauropods. (2) In Tendaguru diplodocids (Barosaurus africanus, Dicraeosaurus hansemanni and Dicraeosaurus sattleri) that have longer hind limbs than fore limbs, the rear limbs and pelvic elements are dominant. (3) In Tendaguru brachiosaurids (Brachiosaurus) that have longer fore limbs than hind limbs, the anterior appendicular skeleton with its huge fore limbs and shoulder girdle dominate the fossil record.

Body-part representation is strongly influenced by the degree of carcass decay that was reached before burial. Therefore, the taphonomic pattern found is not only an "overprinting" of distinctive skeletal traits of the sauropod skeletons. It also suggests a considerable amount of pre-burial sorting of dinosaur bones in the Tendaguru Beds. The presence of tiny and very delicate pterosaurian and mammalian remains in the Middle and Upper Saurian Bed at Tenda- 


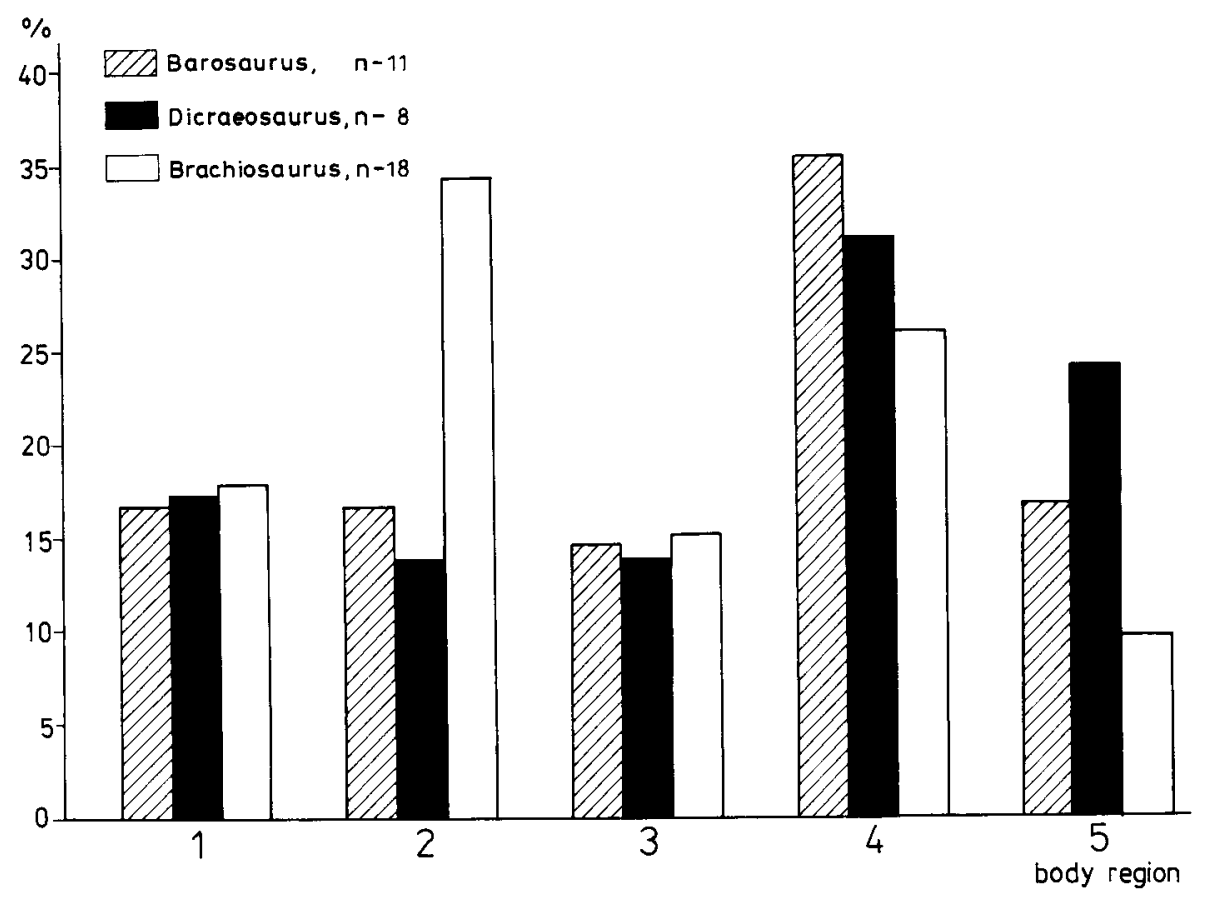

Fig. 20. Frequency distribution of main body regions in sauropod skeletons from Tendaguru. For explanation see text. 1 skull and neck, 2 - shoulder girdle and fore limbs, $\mathbf{3}$ - sacral and dorsal vertebrae, dorsal ribs, 4 - pelvic elements and posterior limbs, $\mathbf{5}$ - tail guru (Reck 1931, Galton 1980, Unwin \& Heinrich 1999, Dietrich 1927, Heinrich 1998, 1999) indicates, however, that this taphonomic pattern cannot be due to post-burial destruction of smaller sauropod skeletal elements.

\subsection{Burial position}

The burial position of carcasses of dinosaurs is difficult to assess because of the relatively small number of reasonably complete skeletons recovered from the Tendaguru Beds. Moreover, the skeletons documented in the field sketches display different burial positions.

The specimen of the dryosaurid Dryosaurus lettow-vorbecki recovered from the Middle Saurian Bed at Site Jg (WJ) was buried on its belly, with the left femur spread away from the trunk, and a cervical vertebral column that was not straight or only slightly recurved (Fig. 13). The skull and neck were apparently still articulated.

Russell et al. (1980: 172) mentioned that Tendaguru barosaurs "preferred to die laying on their left side". The upright position of both left humerus and left tibia of skeleton SII of the brachiosaurid Brachiosaurus brancai (Fig. 16) suggests that the animal became mired in soft mud and died laying on its belly. In-situ decomposition of soft tissues is indicated by the series of articulated cervical vertebrae as well as by parallel oriented dorsal ribs resting closely on each other (Fig. 16). Except for the cervical vertebrae, the majority of skeletal elements are concen- trated close to these two limb bones, indicating that dispersal of bones was minimal. The place of death must therefore have been the place of final deposition.

\subsection{Individual size and age class distributions}

The following account of the size distribution of Tendaguru sauropods (Brachiosaurus brancai, Barosaurus africanus) is based upon the humeri and femora, and that of the ornithischians (Dryosaurus lettow-vorbecki) upon the femora, because these bones are better represented in the collection than other limb bones of these taxa. Metric data were taken from Janensch (1961a and unpublished) and from Sander (1999, in press), augmented by my own measurements.

The number of the measured specimens is rather small, making quantitative assessments difficult. Therefore, sauropod specimens from different dinosaur-bearing horizons were put together to form time-averaged populations, as explained in the diagrams (Figs 21 and 22). Both humeri and femora of Brachiosaurus brancai were assigned to $30.0 \mathrm{~cm}$ intervals, those of Barosaurus africanus to $14.0 \mathrm{~cm}$ intervals. Lifeage data of sauropod individuals are based on histological examinations by Sander (1999, in press).

A data set published by Janensch (1961b) as well as my own measurements can be used to establish a femur-size distribution-diagram for 
Dryosaurus lettow-vorbecki. The femora of Dryosaurus lettow-vorbecki are assigned to $5.0 \mathrm{~cm}$ intervalls. The diagram (Fig. 23) is based on a collection of femora recovered from the Middle Saurian Bed at Tendaguru Site Jg (WJ) Unfortu-
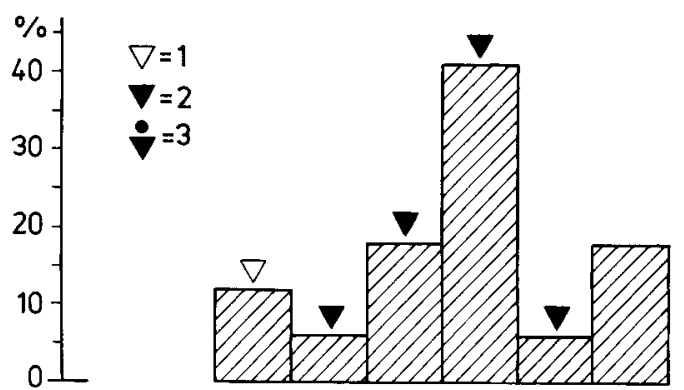

$\mathrm{n}=17$

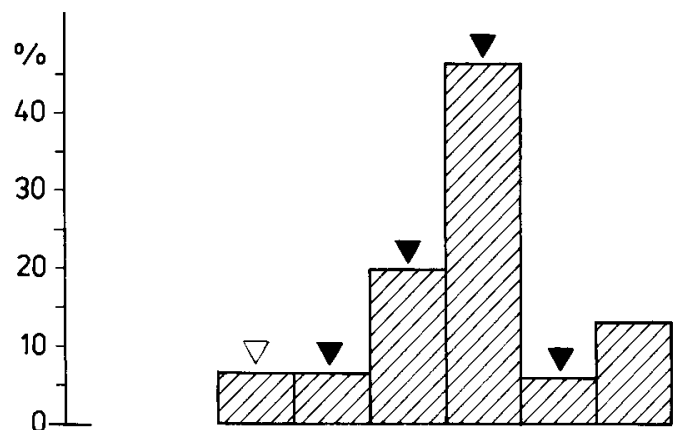

$n=15$
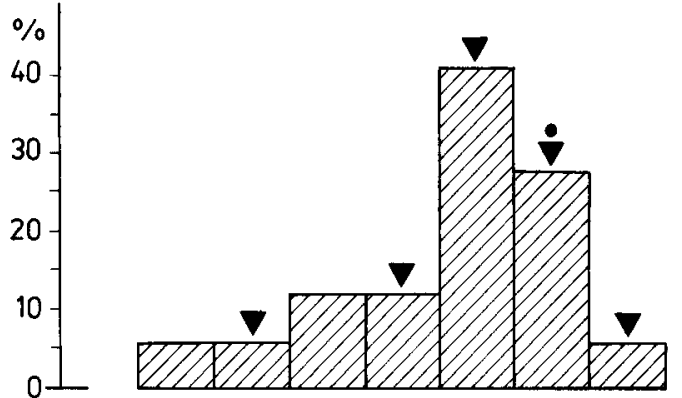

$n=17$

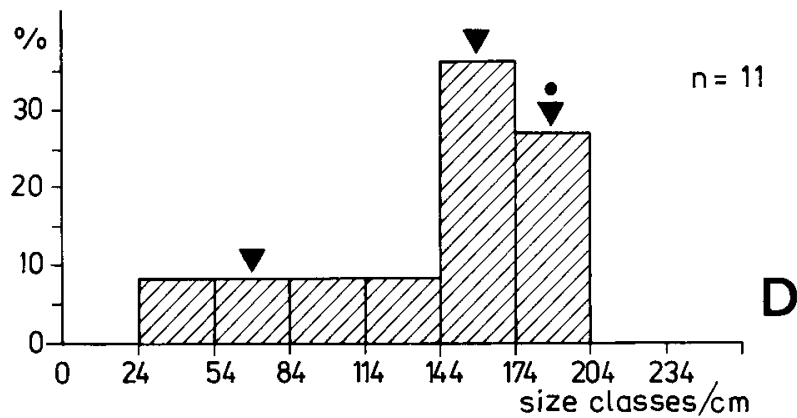

Fig. 21. Size-class distribution of humeri and femora of $\mathrm{Bra}$ chiosaurus brancai from Tendaguru. Data grouped together as follows: A - subset of humeri from the Middle Saurian Bed $(\mathrm{n}=3)$, Upper Saurian Bed $(\mathrm{n}=12)$, and Transitional Sands overlaying the Trigonia smeei $\operatorname{Bed}(\mathrm{n}=2), \mathbf{B}-$ subset of humeri from the Middle Saurian Bed $(n=3)$ and Upper Saurian Bed $(n=12), \mathbf{C}$ - subset of femora from the Middle Saurian Bed $(n=11)$, Upper Saurian Bed $(n=3)$ and Transitional Sands $(n=3)$, $\mathbf{D}$ - subset of femora from the Middle Saurian Bed $(\mathrm{n}=11) . \mathbf{1}$ - juvenile individuals; $\mathbf{2}$ - adult individuals; $\mathbf{3}$ - old adult individuals. The age determination is based upon life history studies by Sander (1999, in press). Metric data from Janensch (1961a), Sander (1999, in press) and own measurements nately, histological data that could calibrate the size classes with ontogenetic data are not available. Paleohistological studies on femora of Dryosaurus lettow-vorbecki from Tendaguru indicate rapid and uninterrupted growth (Chinsamy 1995).

Fig. 21 shows the humerus- and femur-size distribution of Brachiosaurus brancai. The histograms reveals that the populations are dominated by humeri and femora ranging in length from 144 to $174 \mathrm{~cm}$. Based on life history studies by Sander (1999, in press), humeri and femora of these dimensions are probably assignable to

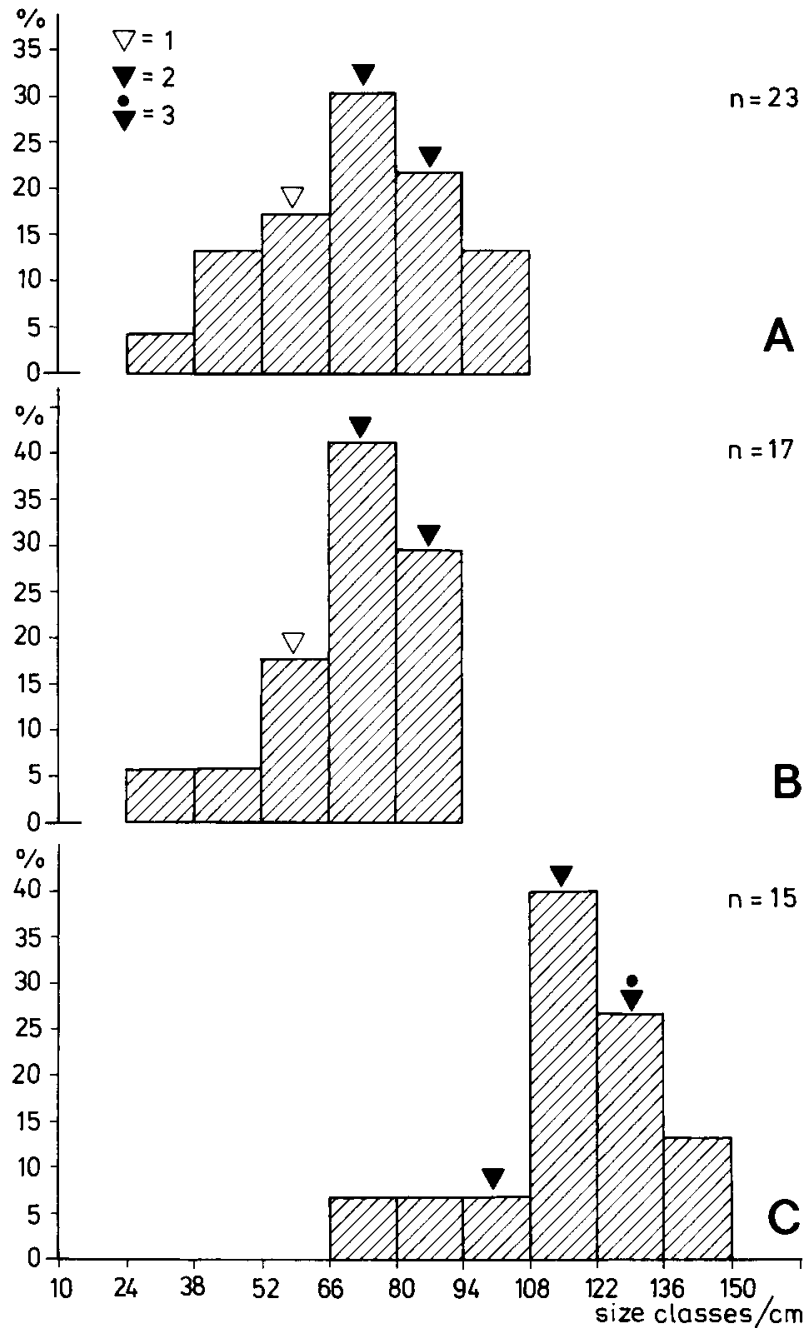

Fig. 22. Size-class distribution of humeri and femora of Barosaurus africanus from Tendaguru. Data grouped together as follows: $\mathbf{A}$ - subset of humeri from the Upper Saurian Bed $(\mathrm{n}=5)$, and Transitional Sands overlaying the Trigonia smeei Bed $(n=18), \mathbf{B}-$ humeri from the Transitional Sands overlaying the Trigonia smeei Bed $(\mathrm{n}=17), \mathbf{C}$ - subset of femora from the Upper Saurian Bed $(n=7)$, and Transitional Sands overlaying the Trigonia smeei $\operatorname{Bed}(\mathbf{n}=8) .1$ - juvenile individuals; $\mathbf{2}$ - adult individuals; $\mathbf{3}$ - old adult individuals. The age determination is based on life history studies by Sander (1999, in press). Data from Janensch (1961a), Sander (1999, in press) and my own measurements 
adult individuals. Adult individuals have also been found in the adjacent humerus size classes $(114-143 \mathrm{~cm}, 174-203 \mathrm{~cm})$, suggesting that about $60 \%$ of the measured specimens of $\mathrm{Bra}$ chioaurus brancai may belong to adult individuals. Old adult individuals are most likely represented in the highest humeri-size class $(204-233 \mathrm{~cm})$.

Humeri of juvenile individuals of Brachiosaurus brancai are distinctly underrepresented, and neonates have not been found so far (Figs. 21A, 21B). The "first" appearance of old adult individuals in femur-size class $174-203 \mathrm{~cm}$ and the "last" appearance of adults in femur-size class $204-233 \mathrm{~cm}$ (Figs. 21C, 21D) indicates that the age groups overlap to significant degree, and include individuals of different size. A similar interval of overlap is to be expected between juvenile and adult specimens.

Consideration of the size frequency histograms for the humerus and femur of Barosaurus africanus reveals that adult individuals apparently prevail (Fig. 22), as in Brachiosaurus brancai. Diagram 22A, which approaches a unimodal size-class distribution is difficult to assess, since

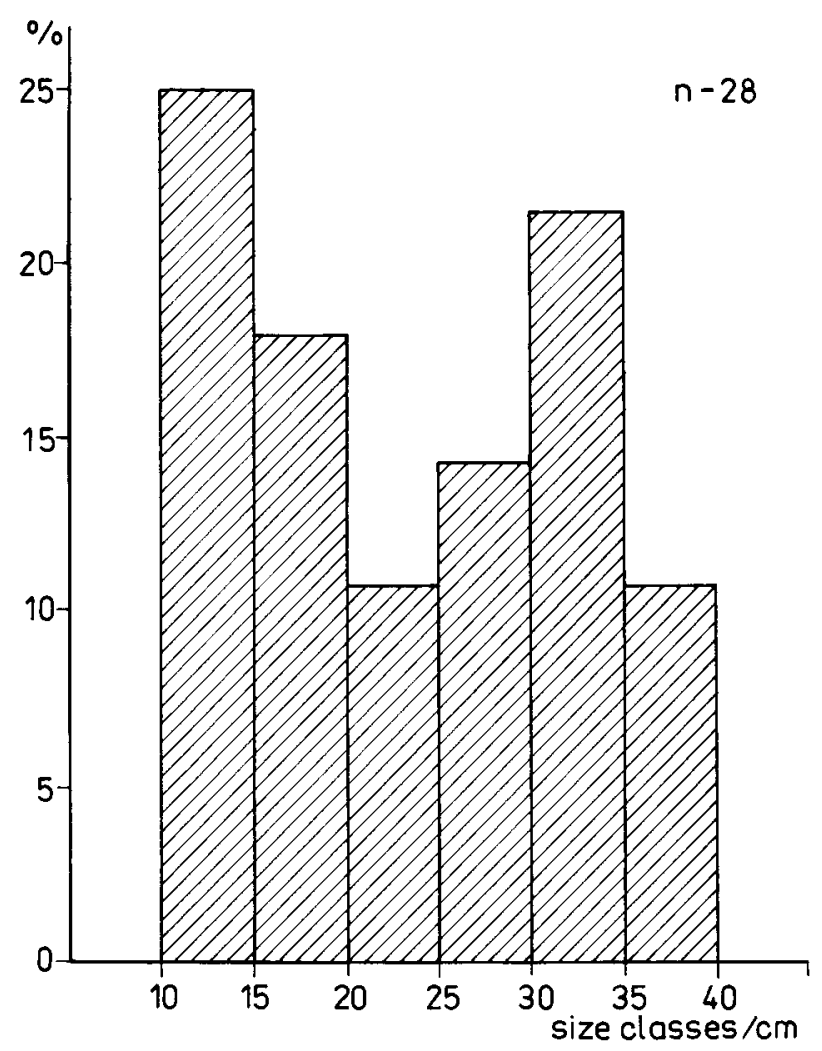

Fig. 23. Size-class distribution for the femur of Dryosaurus lettow-vorbecki from the Middle Saurian Bed at Tendaguru Site Jg (WJ). Metric data from Janensch (1961b: 164) and measurements obtained from recently recovered femora. Total number of femora: 28 the sample is based on time-averaged bone assemblages.

In this connection, it is worth mentioning that histological data obtained from three humeri of Dicraeosaurus sattleri from the Upper Saurian Bed (Sites ab and O) also suggest that adult individuals predominate in the bone assemblages (Sander 1999, in press), as is the case for Brachiosaurus brancai and Barosaurus africanus. A femur of Janenschia robusta collected from the Upper Saurian Bed at Tendaguru Site 22 is attributable to an old adult individual (Sander 1999, in press).

Dryosaurus lettow-vorbecki (Fig. 23) displays a bimodal femur-size-distribution, with two peaks, one at the beginning and one close to end of the plot, suggesting either that juvenile and adult individuals prevail or that sexual dimorphism occurs. Sexual dimorphism cannot be excluded with certainty, but it seems more likely that the bimodality is the result of individual size variation. If this is correct, the pattern of size-distribution may allow conclusions to be drawn regarding on the origin of the mass accumulations of Dryosaurus lettow-vorbecki, discussed below.

\subsection{Attritional or mass mortality?}

The origin of the extraordinary concentrations of dinosaur bones in the Tendaguru Beds has been the of subject of speculations ever since the first discovery of dinosaurs in the Tendaguru area. The interpretation has to consider attributes of the recovered bone assemblages, paleoecological aspects, and pecularities of the depositional environment that influenced the involved taphonomical processes.

According to Janensch (1914a, c; 1961a), the dinosaur-bearing deposits were possibly laid down in a lagoonal environment separated from the sea by reefs. The sedimentation was thought to have been affected by tides, episodic storms (hurricanes), wind waves, earthquakes, and changes in the regional climate (Janensch 1914c). The invertebrate fossil record suggests a brackish to limnic depositional environment for the Middle and Upper Saurian Bed (Dietrich 1914; Hennig 1914b, c; Schudack 1999; Schudack et al. 1999), and records of Asmussia (= Estheria) from the Upper Saurian Bed may indicate periods of drought (Janensch 1933, Russell et al. 1980).

As mentioned above, Janensch (1914c) suggested that the dinosaur bone assemblages from 
Tendaguru resulted mainly from abrupt catastrophic killing events. Unfortunately, the precise relationships of the quarried dinosaur bones to the enclosing sediments are far from clear, due to the loss of many records. In addition, the precise stratigraphic position of the dinosaur-bearing sites within the Lower, Middle, and Upper Saurian Bed is unknown. This is especially regrettable, since the depositional environment of the Tendaguru Beds underwent remarkable changes during the Late Jurassic and Early Cretaceous. The dinosaur-bearing sites in the Transitional Sands that connect the Saurian Beds with the shallow marine sandstone beds are undoubtedly marginal marine in origin because marine invertebrates are associated with the dinosaurs. A humerus of Brachiosaurus brancai covered by oysters is reported, for instance, from Site Aa which is in the Transitional Sands above the Middle Saurian Bed (Janensch, GTE field catalogue: 140). As previously mentioned, the state of preservation of bones recovered from the Transitional Sands suggests transport and redeposition of bones prior to burial. Therefore, these enormous concentrations of disarticulated dinosaurs bones probably represent time-averaged bone accumulations rather than a short-term mass mortality event.

As mentioned above, most of the documented skeletal accumulations from the Middle and Upper Saurian Beds are single-individual and monospecific. Multi-individual assemblages are rare, and death assemblages of Brachiosaurus brancai, Dicraeosaurus sattleri, and Barosaurus africanus are apparently dominated by limb bones of adult individuals. This taphonomic pattern does not necessarily support the catastrophic mass mortality model, since killing agents that produced mass mortality should have affected all individual age classes of the sauropod populations.

However, this conclusion should be made with caution because actualistic studies on large extant land mammals reveal that patterns of bone accumulations may result from patterning in behaviour (Haynes 1993). Younger African elephants, for instance, sometimes die "much nearer the inner areas" of die-off sites "than older individuals" due to aggressive interactions at excavated wells during severe drought (Haynes 1993:131). As in extant African elephant populations (Haynes 1990, 1993), seasonal drought could have resulted in social fissioning and ephemeral aggregations of adult and old adult Tendaguru sauropods at shrinking water sources and feeding sites.
In addition, articulated sauropod limb bones buried in an upright position (Janensch 1914c) indicate that the body weight of the animals could have been an important selective taphonomic filter for the dinosaurs from Tendaguru. So, for instance, the body weight of the juvenile Tendaguru sauropods may have been below the threshold for becoming stuck in the mud, unlike the adult animals that passed more frequently the "point of no return" due to their heavier body weight.

A similar taphonomic model has been suggested for the Late Triassic (Norian) prosauropods Plateosaurus (Sander 1992) and Sellosaurus (Hungerbühler 1998). Sander (1992: 256) argues that the absence of juvenile individuals of Plateosaurus engelhardti in several European Knollenmergel sites is due to the "lower foot pressure" of juvenile animals that were thus "below the threshold for becoming mired" in shallow depressions.

Hennig (1925) believed that spatially limited mass accumulations of disarticulated bones of Kentrosaurus aethiopicus from the Middle Saurian Bed (Site St) and the Upper Saurian Bed (e.g., Sites $\mathrm{He}$ and $\mathrm{X}$ ), containing individuals of various size and age, resulted from a sudden mass death event (see also Weigelt 1927). Rich concentrations of disarticulated skeletal remains of Dryosaurus lettow-vorbecki recovered from the Middle Saurian Bed at Site $\mathrm{Jg}$ (WJ) were also thought to represent an instance of sudden mass mortality (Janensch 1914c). Most limb bones (e.g., femur, tibia, fibula) were found parallel to one another, with their long axis oriented northwest to southeast, indicating that these bones were accumulated under the influence of wave action (breakers) or wave-induced currents (Janensch 1914c: 256). Janensch (1914c) supposed that herds of small ornithischians that had entered lagoons during periods of drought were killed by the returning flood and became embedded close to the place of death. If this scenario is correct, Dryosaurus lettow-vorbecki left rapidly formed mass assemblages of bones in the Tendaguru Beds that resulted from an external catastrophic killing event. Accumulations of sauropod bones in the Middle and Upper Saurian Beds are also thought to have been caused by similar killing events, since the huge sauropod dinosaurs were also considered to be gregarious land animals (Janensch 1914c).

By contrast, Reck (1925) who quarried Tendaguru Site Jg (WJ) in 1912 doubted the cata- 
strophic mass mortality. He argued (Reck 1925: 9-10): "So sehr auch das herdenartige Auftreten einzelner Arten, und besonders die Herdenzusammensetzung aus Tieren jeder Größe und jeden Alters für sie zu sprechen scheint, so stehen doch auch ihr unüberwindliche Hindernisse entgegen, wenn man dem Sprachgebrauch entsprechend unter Katastrophe nur ein seltenes, verheerendes Naturereignis versteht ..... Aber zwei Hauptmomente führen ..... zur Ablehnung solcher Theorie: die großzügig gleichmäßigen, außer durch die Transgressionen nicht unterbrochenen, feinklastischen Sedimentationsverhältisse und die regellose Verteilung der Funde in der Vertikalen innerhalb der Mergelmassen. Dadurch wird die Supposition jeder Katastrophe unhaltbar, wenn man nicht jeweils einen ganzen Mergelhorizont als Niederschlag und Zeugnis einer Katastrophe ansprechen will. Dagegen aber spricht alles ..... Als generelles Entstehungsprinzip der Lagerstätte kommt ..... die Katastrophe nicht in Betracht". Reck (1925), on the basis of his studies of the Tendaguru region, concluded that the dinosaur bones were irregularly dispersed within the Tendaguru saurian beds, and that the origin of the bone acumulation could not be explained by catastrophic mass mortality. This distribution pattern suggests that the bone accumulations resulted from recurring "normal" death events of dinosaur individuals over a long period of time rather than from a catastrophic, short-term mass mortality event.

In addition to this argument, further support for an attritional origin is found in the femur-size distribution pattern of Dryosaurus lettow-vorbecki which represents an age profile, dominated by juvenile and adult individuals (Fig. 23). This pattern (Fig. 23) shows a striking similarity to the so-called U-shaped or attritional mortality type of profile that is due to a long-term input of bones resulting from "normal", ecologically related deaths in different-aged population members (Lyman 1996). This pattern differs remarkably from the unimodal L-shaped, catastrophic or mass mortality pattern in which younger age classes dominate and older age classes become successively underrepresented (Lyman 1996). At the present stage of investigation, I do not draw the conclusion, that the mortality profile in Dryosaurus lettow-vorbecki is attritional in origin, since possible influence of the sexual dimorphism is far from clear and the interpretation of U-shaped mortality profiles is mainly based on experience with extant and fossil mam- mals. Nevertheless, it is worth noting, that the interpretation as an attritional mortality profile also agrees more closely with the data obtained from the Tendaguru sauropods (Figs. 21, 22) as well as with the distribution pattern of bones within the Tendaguru dinosaur beds.

The invertebrate fossil record and seasonality indicated by reworked caliche nodules might indicate playa lake-like water bodies close to an oscillating shoreline, and subject to either seasonal or long-term droughts. Cross-bedded sandstone beds within the Middle and Upper Saurian Beds, in turn, might be explained by seasonally rainy intervals that resulted in water flows, temporary lakes, and ponds. These ephemeral water bodies might have been refuges and die-off sites for Tendaguru dinosaurs during seasonal drought. Most likely, the palaeoenvironment in the Tendaguru region was much more diverse than generally thought so far.

In the absence of direct taphonomic studies and substantial parts of the doumentation of the original expedition, it is beyond the scope of the present account to establish a detailed taphonomic model for the Tendaguru dinosaur accumulation. However, the existence of a number of superimposed dinosaur-bearing horizons (Saurian Beds, Transitional Sands) shows that dinosaur bones were accumulated over a long time span during the Late Jurassic. The fossil record also reveals that extraordinarily suitable conditions for the preservation of dinosaurian bones occured repeatedly. The year-to-year input of bones resulting from short-term intervals of mortality due to drought might have been considerable and "simulates" sudden catastrophic mass mortality events. If so, the Tendaguru fossil record may reflect attritional mortality rather than sudden catastrophic mass mortality.

\section{Acknowledgements}

I am grateful to Prof. Dr. H.-P. Schultze and Dr. D. Unwin (Museum für Naturkunde der Humboldt-Universität zu Berlin, Institut für Paläontologie) for much-valued comments and improvement of the English, and to Dr. E. Cook (University of Bristol) for reviewing the manuscript. I extend my thanks, to Dr. P. M. Sander (Universität Bonn) for discussions and histological data of Tendaguru sauropods, to Dr. B. Curtice and Dr. L. Curtice (Phoenix, AZ, USA) for helping with the identification of cervical vertebrae of Brachiosaurus brancai, to Dr. M. Aberhan (Museum für Naturkunde der Humboldt-Universität zu Berlin, Institut für Paläontologie), Prof. Dr. H. Keupp and Dr. M. Schudack (Freie Universität Berlin, Institut für Paläontologie) for comments on the lithology of the Tendaguru Beds, to Mrs. E. Glass (HumboldtUniversität zu Berlin, Institut für Mineralogie) for X ray diffraction analysis, to Mr. J.-P. Mendau for the redrawing of 
the site maps, to Mrs. V. Heinrich for the diagrams, and to Mrs. W. Harre (all Museum für Naturkunde der HumboldtUniversität zu Berlin) for the photographs. Financial support from the Deutsche Forschungsgemeinschaft (He 2757/1-1) is gratefully acknowledged.

\section{References}

Abel, O. 1927. Lebensbilder der Vorzeit. 637 pp., Fischer, Jena.

Aitken, W. G. 1956. The Jurassic-Cretaceous junction in Tanganyika. - East-Central Regional Committee for Geology, Commission for Technical Cooperation in Africa south of the Sahara 1956: 67-71.

- 1961. Geology and Palaeontology of the Jurassic and Cretaceous of Southern Tanganyika. - Bulletin of the Geological Survey of Tanganyika 31: 1-144.

Behrensmeyer, A. K. 1991. Terrestrial vertebrate accumulations. In Allison, P. A. \& Briggs, D. E. G. (eds.). Taphonomy. Releasing the data locked in the fossil record: 291-335, Plenum Press, New York and London.

Bonaparte, J., Heinrich, W.-D. \& Wild, R. Review of Janenschia WILD, with description of an new sauropod from the Tendaguru Beds of Tanzania, and a discussion on the systematic value of the Sauropoda procoelian caudal vertebrae. - Palaeontographica, Abt. A. (in press).

Branca, W. von 1914. Kurzer Bericht über die von Dr. Reck erzielten Ergebnisse im vierten Grabungsjahre 1912. Archiv für Biontologie 3(1): $61-63$.

Broschinski, A. 1999. Ein Lacertilier (Scincomorpha, Paramacellodidae) aus dem Oberen Jura von Tendaguru/Tansania. - Mitteilungen aus dem Museum für Naturkunde Berlin, Geowissenschaftliche Reihe 2: (this volume)

Chinsamy, A. 1990. Ontogenetic changes in the bone histology of the Late Jurassic Dryosaurus lettow-vorbecki. Journal of Vertebrate Paleontology 15: 96-104.

Colbert, E. H. 1984. The great dinosaurs hunters and their discoveries. 283 pp., Dover Publications Incorporation, New York.

Cox, L. R. 1952. The Jurassic lamellibranch fauna of Cutch (Kachh). No. 3: Families Pectinidae, Amusiidae, Plicatulidae, Limidae, Ostreidae and Trigonidae (Supplement). India Geological Survey Memoires, Palaeontologica Indica, ser. 9, vol. 3, part 4: 1-128.

Dietrich, W. O. 1914. Die Gastropoden der Tendaguruschichten, der Aptstufe und der Oberkreide im südlichen Deutsch-Ostafrika. - Archiv für Biontologie 3(4): 97-153.

- 1925. Über eine dem mittleren Sauriermergel am Tendaguru äquivalente, rein marine Kimmeridgebildung in Mahokondo, Deutsch-Ostafrika. - Palaeontographica, Supplement VII, 2. Reihe, Teil I, Lieferung 1: 1-24.

- 1927. Das Alter der Trigonienschichten am Tendaguru. Centralblatt für Mineralogie, Geologie und Paläontologie, B 1927(2): 59-64.

- 1933. Zur Stratigraphie und Palaeontologie der Tendaguruschichten. - Palaeontographica, Supplement VII, 2. Reihe, Teil II, Lieferung 1: 1-86.

Fraas, E. 1908. Ostafrikanische Dinosaurier. - Palaeontographica 55: 105-144.

Galton, P. M. 1980. Avian-like tibiotarsi of pterodactyloids (Reptilia Pterosauria) from the Upper Jurassic of East Africa. - Palaeontologische Zeitschrift 54(3/4): 331-342.

- 1981. Dryosaurus, a hypsilophodontid dinosaur from the Upper Jurassic of North America and Africa. - Paläontologische Zeitschrift 55(3/4): 271-312.

- 1982. Elaphrosaurus, an ornithomimid dinosaur from the Upper Jurassic of North America and Africa. - Paläontologische Zeitschrift 56(3/4): 265-275.

Haynes, G. 1990. The mountains that fell down: life and death of Heartland mammoth. In Agenbroad, L. D.,
Mead, J. I, Nelson, L. W. (eds.). Megafauna and man: discovery of America's Heartland: 22-31, The Mammoth Site of Hot Springs, South Dakota Incorporation, Hot Springs, South Dakota.

- 1993. Mammoths, mastodonts \& elephants. Biology, Behavior, and fossil record. $413 \mathrm{pp}$. Cambridge University Press, Cambridge.

Heinrich, W.-D. 1991. Über Brancatherulum tendagurense DiETRICH, 1927 (Mammalia: Eupantotheria) aus dem Oberjura von Tendaguru, Tansania. Vorläufige Mitteilung. - Mitteilungen aus dem Zoologischen Museum Berlin 67(1): 97-104.

- 1998. Late Jurassic mammals from Tendaguru, Tanzania, East Africa. - Journal of Mammalian Evolution 5(4): 269-290.

- 1999. First haramiyid (Mammalia, Allotheria) from the Mesozoic of Gondwana. - Mitteilungen aus dem Museum für Naturkunde Berlin, Geowissenschaftliche Reihe 2: $159-170$.

Hennig, E. 1912a. Die Entstehung der Dinosaurier-Lager. Sitzungsberichte der Gesellschaft naturforschender Freunde 1912: 137-142, Berlin.

- 1912b. Am Tendaguru. Leben und Wirken einer deutschen Forschungsexpedition zur Ausgrabung vorweltlicher Riesensaurier in Deutsch-Ostafrika. 151 pp., E. Schweitzerbart'sche Verlagsbuchhandlung, Stuttgart.

- 1914a. Paläontologische Ausgrabungen in Deutsch-Ostafrika. - Blätter der Mitglieder des wissenschaftlichen Centralvereins 1914: 1-16. Stuttgart.

- 1914b. Beiträge zur Geologie und Stratigraphie DeutschOstafrikas. I. Geologisch-stratigraphische Beobachtungen im Küstengebiet des südlichen Deutsch-Ostafrika. II. Geologisch-stratigraphische Beobachtungen im Gebiete der Jura-Ablagerungen an der Deutsch-Ostafrikanischen Zentralbahn. - Archiv für Biontologie 3(3): 1-72.

- 1914c. Die Invertebraten-Fauna der Saurierschichten am Tendaguru. - Archiv für Biontologie 3(4): 155-185.

- 1915. Kentrosaurus aethiopicus der Stegosauride des Tendaguru. - Sitzungsberichte der Gesellschaft naturforschender Freunde Berlin 1915: 219-247.

- 1916. Zweite Mitteilung über den Stegosauriden vom Tendaguru. - Sitzungsbericht der Gesellschaft naturforschender Freunde Berlin 1916: 175-182.

- 1925. Kentrurosaurus aethiopicus: die Stegosaurierfunde vom Tendaguru, Deutsch-Ostafrika. - Palaeontographica, Supplement VII, 1 Reihe, Teil 1, Lieferung 2: 100-253.

- 1937. Der Sedimentstreifen des Lindi-Kilwa-Hinterlandes (Deutsch-Ostafrika). - Palaeontographica, Supplement VII, 2. Reihe, Teil II, Lieferung 2, 99-186.

Hungerbühler, A. 1998. Taphonomy of the prosauropod dinosaur Sellosaurus, and its implication for carnivore faunas and feeding habits in the Late Triassic. - Palaeogeography, Palaeoclimatology, Palaeoecology 143: 1-29.

Jaeger, H. 1971. Werner Janensch 1878-1969. - Berichte der Deutschen Gesellschaft für geologische Wissenschaften, A, Geologie, Paläontologie 16(2): 149-154.

Janensch, W. 1914a. Bericht über den Verlauf der Tendaguru-Expedition. - Archiv für Biontologie 3(1): 17-58.

- 1914b. Übersicht über die Wirbeltierfauna der Tendaguru-Schichten, nebst einer kurzen Charakterisierung der neu aufgestellten Arten von Sauropoden. - Archiv für Biontologie 3(1): $81-110$.

- W. 1914c. Die Gliederung der Tendaguru-Schichten im Tendaguru-Gebiet und die Entstehung der Saurier-Lagerstätten. - Archiv für Biontologie 3(3): 227-261.

- 1920. Über Elaphrosaurus bambergi und die Megalosaurier aus den Tendaguru-Schichten Deutsch-Ostafrikas. - Sitzungsberichte der Gesellschaft naturforschender Freunde Berlin 1920: 225-235.

- 1922. Das Handskelett von Gigantosaurus robustus und Brachiosaurus brancai aus den Tendaguru-Schichten Deutsch-Ostafrikas. - Centralblatt für Mineralogie, Geologie und Palaeontologie 1922: 464-480. 
- 1925a. Die Grabungsstellen der Tendaguru-Gegend. Palaeontographica, Supplement VII, 1 Reihe, Teil 1, Lieferung 1: XVII-XIX.

- 1925b. Die Coelurosaurier and und Theropoden der Tendaguru-Schichten Deutsch-Ostafrikas. - Palaeontographica, Supplement VII, 1 Reihe, Teil 1, Lieferung 1: 1-97.

- 1929a. Material und Formengehalt der Sauropoden in der Ausbeute der Tendaguru-Expedition. - Palaeontographica, Supplement VII, 1 Reihe, Teil 2, Lieferung 1: 1-34.

1929b. Die Wirbelsäule der Gattung Dicraeosaurus. - Palaeontographica, Supplement VII, 1 Reihe, Teil 2, Lieferung 1: $37-133$.

- 1929c. Ein aufgestelltes und rekonstruiertes Skelett von Elaphrosaurus bambergi. Mit einem Nachtrag zur Osteologie dieses Coelurosauriers. - Palaeontographica, Supplement VII, 1 Reihe, Teil 2, Lieferung 1: 279-286.

- 1933. Eine Estheria aus den Tendaguruschichten. - Palaeontographica, Supplement VII, 2 Reihe, Teil 2, Lieferung 1: 95-98.

- 1935. Die Schädel der Sauropoden Brachiosaurus, Barosaurus und Dicraeosaurus aus den Tendaguru-Schichten Deutsch-Ostafrikas. - Palaeontographica, Supplement VII, 1 Reihe, Teil 2, Lieferung 1: 145-248.

- 1936. Über Bahnen von Hirnvenen bei Saurischiern und Ornithischiern, sowie einigen anderen fossilen und rezenten Reptilien. - Palaeontologische Zeitschrift 17: 181-198.

- 1938. An African Dinosaur. - Research and Progress 4(5): $276-278$.

- 1950a. Die Wirbelsäule von Brachiosaurus brancai. - Palaeontographica, Supplement VII, 1. Reihe, Teil III, Lieferung 2: 27-93.

- 1950b. Die Skelettrekonstruktion von Brachiosaurus brancai. - Palaeontographica, Supplement VII, 1. Reihe, Teil III, Lieferung 2: 95-103.

- 1950c. Die systematische Stellung des Ornithopoden Dysalotosaurus aus den Tendaguru-Schichten. - Neues Jahrbuch für Geologie und Paläontologie, Mh., 1950(9): $286-287$

- 1955. Der Ornithopode Dysalotosaurus der Tendaguruschichten. - Palaeontographica, Supplement VII, 1 Reihe, Teil 3, Lieferung 3: 105-176.

- 1961a. Die Gliedmaßen und Gliedmaßengürtel der Sauropoden der Tendaguru-Schichten. - Palaeontographica, Supplement VII, 1. Reihe, Teil III, Lieferung 4: 177-235.

- 1961b. Skelettrekonstruktion von Dysalotosaurus lettow. vorbecki. - Palaeontographica, Supplement VII, 1. Reihe, Teil III, Lieferung 4: 237-240.

Janensch, W. \& Hennig, E. 1909. Erster Bericht über die Tendaguru-Expedition. - Sitzungsberichte der Gesellschaft naturforschender Freunde Berlin 1909: 358-360.

Kapilima, S. 1984. Stratigraphische und paläontologische Untersuchungen im Jura und der Kreide des tansanischen Küstenstreifens im Hinterland von Dar-Es-Salaam und Bagamoyo. - Berliner Geowissenschaftliche Abhandlungen, A, 57: 1-77.

Kent, P. E., Hunt, J. A. \& Johnstone, D. W. 1971. The geology and geophysics of costal Tanzania. - Natural Environment Research Council, Institute of Geological Sciences, Geophysical Paper 6: I-VI, 1-101.

Kitchin, F. L., 1929. On the age of the upper and middle deinosaur deposits at Tendaguru, Tanganyika Territory. Geological Magazine, 66(5): 193-220.

Lange, E. 1914. Die Brachiopoden, Lamellibranchiaten und Anneliden der Trigonia Schwarzi-Schichten. - Archiv für Biontologie 3(4): 187-289.

Lyman, R. L. 1996. Vertebrate Taphonomy. 524 pp. Cambridge University Press, Cambridge.

Migeod, F. W. H. 1927. British Museum East Africa expedition. Progress in the year 1926. - Natural History Magazine 1927(1): $34-43$.

- 1930. Report on the British Museum East Africa expedition. Season 1929. - Natural History Magazine 1930(2): 185-198.
- 1931. British Museum East Africa expedition. Account of the work done in 1930. - Natural History Magazine 1931(3): $87-103$.

Parkinson, J., 1930. The dinosaur in East Africa. An account of the giant reptile beds of Tendaguru, Tanganyika Territory. 192 pp., H. F. \& G. Witherby, London.

Reck, H. 1925. Grabungen auf fossile Wirbeltiere in Deutsch-Ostafrika. - Geologische Charakterbilder 31: $1-36$.

- 1931. Die deutschostafrikanischen Flugsaurier. - Centralblatt für Mineralogie, Geologie und Paläontologie, B, 1931: $321-336$.

Russell, D., Béland, P. \& McIntosh, J. S. 1980. Paleoecology of the dinosaurs of Tendaguru (Tanzania). - Mémoires de la Société Geologique de France, Nouvelle Série, 139: $169-175$.

Sander, P. M. 1992. The Norian Plateosaurus bonebeds of Central Europe and their taphonomy. - Palaeogeography, Palaeoclimatology, Palaeoecology 93: 255-299.

- 1999: Life history of the Tendaguru sauropods as deduced from long bone histology. - Mitteilungen aus dem $\mathrm{Mu}-$ seum für Naturkunde Berlin, Geowissenschaftliche Reihe 2: $103-112$.

- (in press) Long bone histology of the Tendaguru sauropods: Implication for growth and biology. - Palaeobiology

Schrank, E. 1999. Palynology of the dinosaur beds of Tendaguru (Tanzania) - preliminary results. - Mitteilungen aus dem Museum für Naturkunde Berlin, Geowissenschaftliche Reihe 2: 171-183.

Schuchert, Ch. 1918. Age of the Morrison and East African Tendaguru formations. - Bulletin of the Geological Society of America 29: 245-280.

- 1934. The Upper Jurassic age of the Tendaguru dinosaur beds. - American Journal of Science 27: 463-466.

Schudack, M. E. 1999. Charophytes from the Middle Dinosaur Member of the Tendaguru Formation (Upper Jurassic of Tanzania). - Mitteilungen aus dem Museum für Naturkunde Berlin, Geowissenschaftliche Reihe 2: 201-205.

Schudack, M. E., Schudack, U. \& Pietrzeniuk, E. 1999. Ostracods from the Middle Dinosaur Member of the Tendaguru Formation (Upper Jurassic of Tanzania). (manuscript)

Spath, L. F. 1927-1933. Revision of the Jurassic cephalopod fauna of Kachh (Cutch). - India Geological Survey Memoires, Palaeontologica Indica, new ser., vol. 9, mem. 2, pt. 1-6: 1-945.

Unwin, D. \& Heinrich, W.-D. 1999. On a pterosaur jaw remain from the Upper Jurassic of Tendaguru, East Africa. - Mitteilungen aus dem Museum für Naturkunde Berlin, Geowissenschaftliche Reihe 2: 121-134.

Weigelt, J. 1927. Rezente Wirbeltierlleichen und ihre paläobiologische Bedeutung. 227 pp., Verlag Max Weg, Leipzig.

Wild, R. 1991. Die Ostafrika-Reise von Eberhard Fraas und die Erforschung der Dinosaurier-Fundstelle Tendaguru. Stuttgarter Beiträge zur Naturkunde, Ser. C, 30: 71-76.

Zeiss, A. 1975. The Aptian ammonite fauna of Ethiopia: new results on the biostratigraphy and zoogeography. - Neues Jahrbuch für Geologie und Paläontologie, Mh., 1975(10): $628-639$.

Zils, W., Werner, Ch., Moritz; A. \& Saanane, Ch. 1995a. Orientierende Tendaguru-Expedition 1994. - Berliner Geowissenschaftliche Abhandlungen E16 (Gundolf-ErnstFestschrift): 483-531.

Zils, W., Werner, Ch., Moritz; A. \& Saanane, Ch. 1995b. Tendaguru, the most famous dinosaur locality of Africa. Review, survey and future prospects. - Documenta naturae 97, 1-41.

Zwierzycki, J. 1914. Die Cephalopodenfauna der TendaguruSchichten in Deutsch-Ostafrika. - Archiv für Biontologie 3(4): 7-96. 